\title{
WILLIAM H. WHYTE JR.: HOW THE CREATOR OF 'GROUPTHINK' WAS FORGOTTEN AND WHY IT MATTERS
}

\section{By}

Oliver Pol

\begin{abstract}
A thesis
submitted to the Victoria University of Wellington

in partial fulfilment of the requirements for the degree of

Master of Commerce in Management
\end{abstract}

Victoria University of Wellington

2020 


\begin{abstract}
$\underline{\text { Abstract }}$
This thesis examines the presentation of management theories in textbooks, focusing on groupthink as an indicative case. The groupthink theory warns that positive consensus leads to the exclusion of other ideas, with potentially disastrous results. It is credited to the psychologist Irving Janis, but William H. Whyte Jr. used the phrase groupthink in 1952 , nineteen years before Janis' first usage. I ask how this happened - why do most textbooks credit Janis if he did not create the term? To answer this, the study takes a critical view of management's dissemination of knowledge. A critical study acknowledges that all knowledge is subjective, and no interpretation can precisely represent the past. The primary method was the collection historical data primarily composed of textbooks, academic studies, and journal articles. This data represents the primary work of Whyte and Janis regarding groupthink, and their representation elsewhere. This allows for the construction of a 'counter-history' to the accepted version of history where Janis is groupthink's creator. My findings demonstrate a clear shift within management history, discovering early evidence of Whyte's groupthink being embraced by prominent writers, followed by a gradual marginalisation of Whyte's contribution. This was due in part to Janis' sudden popularity but it is evident that management studies deliberately moved away from questions of conformity asked by Whyte and peers in the 1950s. I also found that Whyte himself moved away from the groupthink terminology, rebadging the same concept as 'the organization man'. These findings contribute a new case study to the field of management literature calling for the importance of directly embracing history. It also makes a case for textbooks as a study's primary form of data. Future research can further explore the extent of the continued relevance of William $\mathrm{H}$. Whyte's ideas in a modern context.
\end{abstract}




\section{$\underline{\text { Acknowledgements }}$}

Writing this thesis has been a massively solitary experience, and therefore I feel strong gratitude to essentially every human with whom I have had contact during the postgraduate experience. Naming all these people would apparently take too long, however? So:

Friends! Alisdair and Jamie for general excellence and dedication to questionable cinematic experiences. Also all theatre-people: acting and devising and all that jazz (though minimal literal jazz was involved) has kept my positive vibes broadly intact over the last few years special thanks to Tim, Emma and Lily.

Family! Harriet and Charlotte for being siblings, and Ron and Alison for being parents. And yeah, all the support (general). Big respect is also due to all the other bits of the family tree: the living ones for being good people, and the ancestors for contributing to my existence. Existing has been very important for writing this.

Thanks to Stephen Cummings for the contribution on the AOM conference paper, and massive thanks to Todd Bridgman for wonderfully supportive supervision on the thesis, but also for the last couple of years of MGMT202 tutoring: being employed was superb for continuing to pay rent, and the inspirational mentorship was a very nice bonus. 
Table of Contents

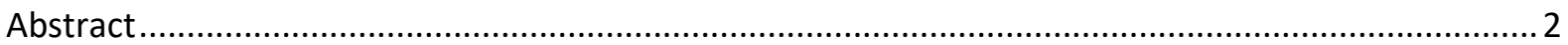

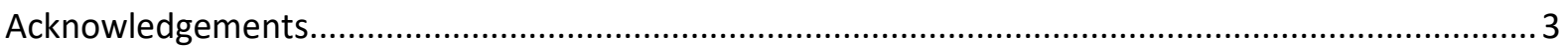

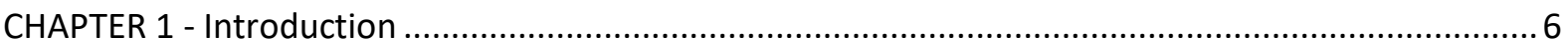

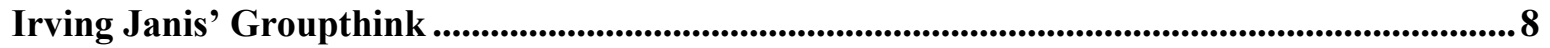

CHAPTER 2 - Literature Review: Making History .................................................................. 11

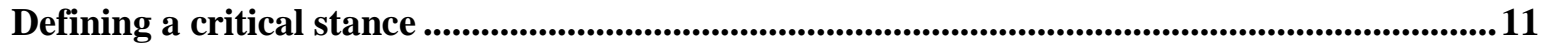

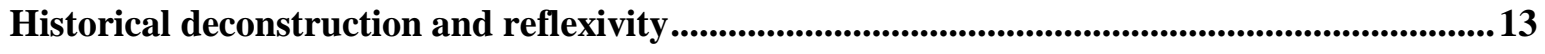

Why the historic turn is valuable......................................................................................... 14

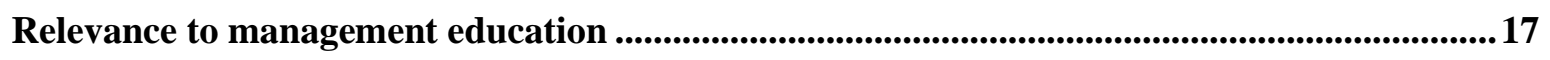

The role of textbooks in limiting historical engagement...................................................18

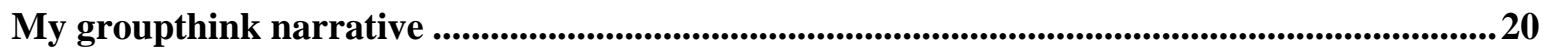

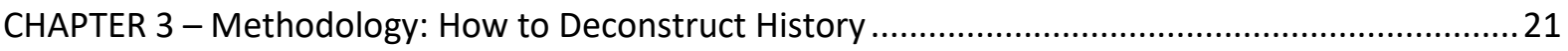

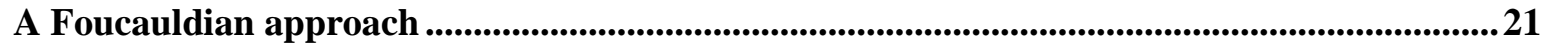

Viewing management history differently ................................................................................ 22

Textbook analysis....................................................................................................................23

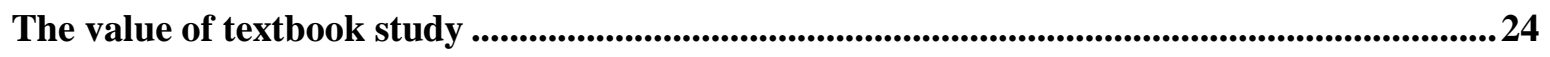

Data collection: Constructing the corpus..........................................................................25

Using individual textbooks to indicate trends ..............................................................26

Representing data: Generalisations and representations.......................................................227

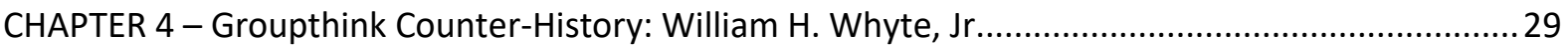

Whyte's early career and groupthink .......................................................................................29

Reception to groupthink and Is Anybody Listening? .........................................................32

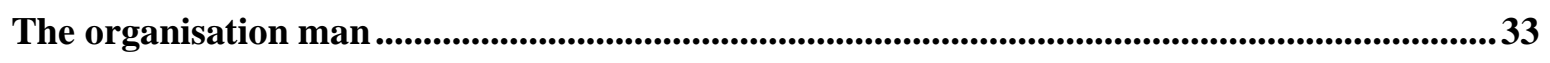

Whyte in context: Management studies in the 1950s .....................................................35

Responses to Whyte beyond the 1950s ......................................................................................37

Changing textbooks: From Whyte to Janis ...........................................................................40

Whyte, out: A change of career ............................................................................................ 42

Death of an organisation man ........................................................................................45

CHAPTER 5 - Strengths and Limitations of Janis' Groupthink ...................................................49

Janis' groupthink provides a simple diagnostic framework for managers ...........................49

Janis' groupthink appeals to textbooks written to train managers..........................................50

Janis' groupthink reinforces the value of group dynamics .....................................................51

Janis' groupthink relates to well-known cases ................................................................52 
Janis' limitations: Minimal progression from initial foreign policy case studies........................53

Janis' limitations: Minimal evidence.............................................................................................54

Conclusion: Groupthink beyond Janis ..................................................................................................56

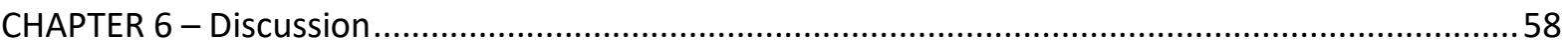

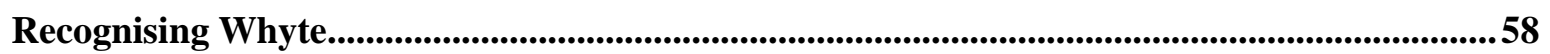

This woman's work: The rigour behind Whyte ...............................................................................59

Conformity: Comparing Whyte and Janis' arguments........................................................59

Whyte now: Does he have a place in the $21^{\text {st }}$ century? .........................................................................6 60

Where does this leave Irving Janis? .....................................................................................................62

Contributions: A new example for critical studies...............................................................63

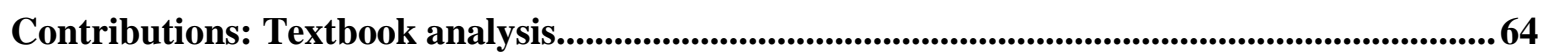

Contributions: A reorientation of textbooks to promote open conversations ..............................65

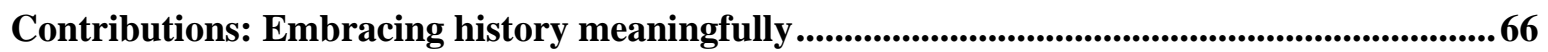

Conclusion: The value of teaching Whyte's ideas ..............................................................................66

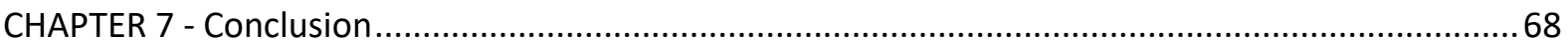

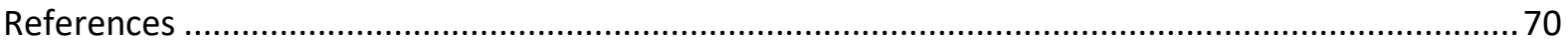




\section{CHAPTER 1 - Introduction}

Groupthink. The concept regularly features in management studies and organisational behaviour textbooks as an important theory in group relations. The book Victims of Groupthink (Janis, 1972) highlighted groupthink as a flaw in group decision-making. The word describes a form of conformity where a group or team all agree with each other about the most appropriate course of action. Even those with doubts suppress these in a desire to avoid conflict and promote harmony, but decisions affected by groupthink are said to regularly result in negative outcomes. The word and concept are usually attributed to prominent psychologist Irving Janis, whose 1971 article and 1972 book on the topic of groupthink are credited with popularising the concept. Janis (1971) described George Orwell's dystopian novel 1984 as influential in the concept's creation. In Orwell's (1949) book, a totalitarian state uses terminology like 'doublethink' to justify their methods of enforcing obedience. With this intentional connotation, Janis made his views on the dangers of conformity clear. He was warning groups of the dangers of seeking concurrence at the expense of more rational considerations. To support this claim, Janis illustrated his theory with practical examples. He analysed instances where he believed groupthink occurred, creating fiascos (or only narrowly avoiding them). And his use of the term fiasco was not unwarranted: the examples selected by Janis all related to significant foreign policy decisions such as the Cuban Missile Crisis, Vietnam War and the Bay of Pigs invasion - infamous blunders at the highest level of government, usually involving the United States (of which Janis was a citizen).

However, groupthink predates Janis. The American journalist William H. Whyte Jr. first used the term in a 1952 article for Fortune magazine. It also appeared in a book published by Whyte later that year, followed by several textbooks and articles referencing the term and citing Whyte for its creation. But these citations rapidly thinned. In the $21^{\text {st }}$ century they are almost non-existent. His connection to the term is now largely unknown, motivating this thesis. If the commonly accepted history of groupthink discusses the term as a Janis creation, my intention is to construct a plausible counter-history of groupthink, tracing the concept's development as a creation of Whyte. 
This can:

- Investigate the similarities and differences between groupthink as defined by Whyte and by Janis.

- Illustrate how the changing field of management has represented groupthink.

- Give a new insight into the rich conformity debates of the 1950s.

- Provide an explanation for why Janis came to be recognised as groupthink's creator.

- Give an indication of the extent to which these historical ideas could be relevant today.

Following a short introduction to the most commonly referenced Janis-inspired version of groupthink, I will outline the findings of my historical study. In Chapter 2 I will address the theoretical foundations of my research, and its intended contributions to literature taking a critical approach to management studies, embracing awareness of history as a vital aspect of future learning. Chapter 3 will set out the methodology for this task. My study was conducted with primarily archival sources, with textbooks as the key primary data to analyse the changing representation of groupthink throughout time. This data was analysed with a Foucauldian methodology, accepting that no version of history is truly objective. The act of researching the past inherently involves creating a narrative. Chapter 4 is where this narrative is constructed. Through close analysis of the historical sources, I offer a counter-history of groupthink in which it is presented as a William H. Whyte idea originating in 1952. This involves outlining early academic references to Whyte and groupthink, and the extent to which these faded away as time passed. The broader career movements of Whyte also form an important part of this narrative. Chapter 5 then returns to the currently accepted version of history, where groupthink is a Janis creation. I endeavour to answer why this is the case, and based on many examples of textbooks' representations of Janis' ideas, I contend that his version of groupthink provides a ready-made framework for textbooks, as well as wellsketched historical case studies from which few textbooks feel the need to stray very far. The discussion in Chapter 6 brings these threads together and argues that Whyte's groupthink could provide a more interesting and more critical contribution to management learning. He did not limit his critique to small groups facing crises (as Janis mostly did) but attacked large organisations and the foundations of human relations itself, in a way that could still be relevant today. I then summarise my contribution to critical literature in providing a new example of the marginalisation of historical management concepts, as well as contributing to the debate about the need for management teaching to embrace its field's rich history. 


\section{Irving Janis' Groupthink}

“Have you ever been in a group where your views didn't match the group's consensus views and you remained silent? Maybe others felt the same way and also remained silent. This is what Irving Janis called groupthink, a form of conformity in which group members withhold deviant, minority or unpopular views in order to give the appearance of agreement".

(Robbins, et al., 2016, 73)

The textbook cited above was co-authored by Stephen Robbins, one of the best-selling management textbook writers of all time. It is a good illustration of groupthink's frequent representation. Before addressing the literature review and the methodology of my historical analysis of groupthink, I will delve into how it is usually represented by textbooks. This exploration will mean defining groupthink (as a Janis creation), as well as exploring Janis' career more broadly. It is valuable to do this because while groupthink is Janis' most prominent contribution to management studies it is not his sole contribution. His significant contribution should be remembered, just not necessarily as groupthink's creator.

Irving Janis was born in 1918 and received a PhD in Psychology in 1947 from Columbia University. During his wartime studies he was drafted into the army and conducted research into military morale (Tetlock, 1991). Though his first article for the Journal of Conflict Resolution about decision-making processes was published in 1959 (Russett, 1991), any of Janis' work on conformity and group decisions is dwarfed in popular consciousness by his discussion of groupthink. The first occasion where Janis and groupthink are explicitly linked is the publication of a 1971 article in the journal Psychology Today. As noted earlier, the article developed Janis' groupthink concept by studying United States foreign policy fiascos such as the failure to anticipate the attack on Pearl Harbor, the Bay of Pigs invasion, and the escalation of the Vietnam War. He argued that these mistakes were made by intelligent and competent people whose decisions were clouded by concurrence-seeking dynamics within the group. A desire for harmony and fear of disagreement and conflict meant that alternative courses of action could not be properly considered.

In his subsequent book, Victims of Groupthink, Janis (1972, 197-198) used common errors observed in his study of historic fiascos to create eight symptoms of groupthink. These are: 
- An illusion of invulnerability which creates unfounded optimism and encourages excessive risk taking.

- Collective rationalisation of evidence to discount warnings that might lead group members to question their assumptions.

- A belief in the inherent morality of the group, therefore often disregarding ethical considerations.

- Stereotyping of outsiders as evil, weak, or stupid.

- Direct pressure on dissenters, highlighting their 'disloyalty' to the group.

- Self-censorship by individuals to minimize the importance of their own doubts or contrary views.

- A shared illusion of unanimity, with silence interpreted as consent.

- Self-appointed 'mind-guards', who protect the group from information that might shatter the apparent consensus.

In Victims of Groupthink, Janis prescribes actions to mitigate these symptoms:

- Assign the role of critical evaluator to encourage the airing of objections.

- Leaders should appear impartial and not state their own preferences.

- Leaders should be open to criticism by other members.

- Set up independent groups working on the same issue.

- Discuss the group's deliberations with others in the organisation and report back their reactions.

- Invite outside experts to group meetings and encourage them to challenge any apparent group consensus.

Janis continued to write about groupthink for the rest of his career, including in a popular 1982 revised edition of his 1972 book. While he added some new cases and adapted some of his analysis, the notion of expressing the concept with analysis of American policy decisions remained unchanged, as did his penchant for listing symptoms and methods to rectify potential groupthink situations. These ideas were quickly adopted by textbooks (Lawless 
1979; Byrt, 1980). Largely unchanged, this representation of groupthink remains a common feature of management textbooks today.

Irving Janis spent most of his working life at Yale, with his studies including work on persuasibility and the effects of stress and frustration (Russett, 1991). It is rare that management textbooks will note Janis' work outside of groupthink, but this work does make some appearances. These citations help to illustrate that Janis' groupthink was informed by several years of interest in group dynamics, despite management not being his field. Mayer et al. (2006) reference research by Hovland, Janis, and Kelley (1953) into communication and attitude change. Lawless $(1972,192)$ references a "famous" study by Janis and Feshbach (1953) into the effects of fear. This psychological study was based around oral hygiene, but Lawless claims a more generalised applicability to management styles. Management textbooks have also featured discussions of Janis' findings that when pressure is exerted to express an opinion that one does not hold, opinions can be genuinely changed (Janis \& King, 1954; cited in Cascio, 1978). Textbooks by Bass (1960) and Sandberg and Targama (2007) discuss Janis and King's (1954) findings regarding passive listeners as less likely to change their opinions, and active interaction leaves them more open to change. Feldman and Arnold (1983) reference Janis and Mann's (1977) work to improve the quality of data available to job seekers. These examples indicate a man interested in the issues of conformity, and with an interest in the employee.

Irving Janis died in 1990. Obituaries discussed his long career marked by many honours in numerous fields, and his texts regarding groupthink were regularly referenced (e.g. Russett, 1991). But while Janis spent much of his life discussing this concept, he never particularly expanded the concept beyond its 1971/2 foreign policy genesis. While it was rapidly picked up by management textbooks, Janis did not actively adapt the theory to be more appropriate to organisational behavior more broadly - the analysis stayed closely tied to the specific case studies. But he did not particularly need to adapt - textbooks evidently liked the term. The next two chapters will set out a framework for critically analysing textbooks, using them as historical data to determine how Janis' groupthink has been presented over the years. This will involve embracing subjectivity and viewing history as a narrative about the past, enabling the creation of a different narrative - a counter-history constructed around Whyte's groupthink in the hope of creating a contrast to the facts that are generally accepted, sparking a more critical and complex argument. 


\section{CHAPTER 2 - Literature Review: Making History}

"The past has occurred. It has gone and can only be brought back again by historians in very different media, for example in books, articles, documentaries, etc., not as actual events. The past has gone and history is what historians make of it when they go to work."

(Jenkins, 1991, 6).

This section will define the 'critical' stance of this research into groupthink, examining literature with similar intent. A critical approach questions the received wisdom about management, positing that it may too often serve the interests of capitalism and its associated hierarchies. Assuming that these systems are fundamentally morally good can lead to excessive focus on managers, ignoring those further down the chain. In outlining this critical approach, I will discuss the repeated calls from authors in this field to attend more closely to the history of management: it is to this strain of management literature that I will make my most significant contribution. This means engaging in a process that must involve distinguishing 'history' from 'the past'. The past refers to events that have occurred, while history is a subjective narrative about the past - a representation of past events rather than an encapsulation. I will outline some of the most notable examples of critical academic approaches to history, and the arguments made for history's relevance to management's future. This growing critical literature can provide powerful insights and provoke the people who shape the field of management, such as educators and textbook writers, to reconsider the possible value of engaging meaningfully with management history to expand the critical thinking and curiosity of students.

\section{Defining a critical stance}

Conceptually I am locating this study within the field of critical management studies. It is generally accepted that this began with Mats Alvesson and Hugh Willmott's edited collection Critical Management Studies (1992). An appropriate working definition of this critical approach is a form of study involving a scepticism of the received wisdom portrayal of management. This received wisdom approach focuses on the design and maintenance of systems and productivity improvements from a managerial perspective. But such a perspective is often blinkered by an inclination to present management as an unproblematic force, shying away from analysis of moral considerations. It often presents management as 
neutral or even self-evidently virtuous and socially valuable (Alvesson \& Willmott, 1992). The critical approach I am taking here questions this approach, guided instead by the belief that "management is too potent in its effects upon the lives of employees, consumers and citizens" (Alvesson \& Wilmott, 1992, 1) to be taken for granted as rational or self-evident, because the representation of knowledge is often presented in a way that disproportionately serves some sets of interests above others. Critical writers highlight management as a social relation - one that can both help and harm (Alvesson \& Willmott, 1996). This approach claims that genuine neutrality is rarely possible. Everything is coloured by power relations, which are often inequal. This is evident in the presentation of management knowledge (of which textbooks are a good example). The role of those with less power can be more easily minimised or obscured. This is not a radical idea: the old adage is that history is written by the winners. But a critical approach to management aims to identify these 'winners' (and losers), and the processes by which they have won the right to shape what is accepted as knowledge.

A critical approach "proposes a fundamental reorientation of management studies" (Zald, 2002, 372), including looking to history. This is distinct from the more frequent tendency of management studies to minimise representation of its history to focus instead on the present and future of the field. A critical approach, however, can argue for history's vitality in understanding and formulating ideas in the present and achieving an informed future. Alfred Kieser (1994) noted that while historical accounts of management and organisation theory existed, they were increasingly simply "myopic fact-collect[ing]" (612). He instead called for genuine integration of history. This still meant maintaining the field's debt to science, but while forging stronger connections with history and other facets of the humanities, including philosophy. Burrell (1997) posited a hostility towards the humanities from management teachers, with business schools looking "outwards towards the market and its perceived needs rather than inwards towards the pursuit of intellectual edification" (186).

But integrating fields like philosophy and history, Kieser argued, could help to illuminate aspects of the social construction of management ideas. This means examining how certain ideas began and how they evolved, becoming more or less prominent over time. This 'historic turn' is distinct from the approach taken by many others in the field where history is too often invoked only to support common-sense ideological assumptions (Clark \& Rowlinson, 2004). These representations of history are presented with the implication that students need not ask questions - Clark and Rowlinson (2004) provide the example of Peters and Waterman's 
(1982) history of IBM's philosophy, of which almost the only source was a book by the son of the founder of IBM - obviously the scope for significant criticism would be diminished. A critical view perceives the need to examine the ideological conflicts and social structures that have shaped management history because an agreed-upon consensus is rarely arrived at without a long process of "struggle between competing and contradictory forces" (Alvesson $\&$ Willmott, 1996, 75). This thesis will illustrate this notion of examining conflict, analysing the early days of the management field in the 1950s, with many writers (including William $\mathrm{H}$. Whyte) criticising an increased reliance on groups and organisations in a time when corporations were increasingly powerful and dominant. A critical approach that embraces history seeks to restore the visibility of such struggles, to maintain a sense of context.

\section{Historical deconstruction and reflexivity}

Alun Munslow (2003) described the assumption that historical facts exist "prior to and independent of interpretation" (Novick, 1988, 1) as a reconstructionist approach to history. This is based on a strong belief in empiricism, a theory stating that knowledge comes only from sensory experience. This is a very common view of history, and as is implied by the term reconstructionist, the goal is to recreate the past in the most accurate way possible, and therefore understand its meaning. It is believed that this 'likely meaning' can be found by closely studying historical sources. Munslow did not believe that this was feasible. He favoured a perspective that he described as deconstructive. To achieve a historically deconstructive point of view, a distinction must be made between the past and history, with history as "a discourse about the past" (Jenkins, 1991, 6). This position accepts that history's content "derives its meaning as much by the representation of that content, as by research into the sources" (Munslow, 2003, 6). This means embracing the fact that history can never truly reconstruct the past. The past is every event that has happened before now, and it is gone forever. History can only offer a representation of the past. A critical approach to management history does not necessarily seek to negate or supersede traditional reconstructionist conceptions of history but aims to always provide an alternative, challenging dominant assertions (Alvesson et al., 2009, 10). This involves an inherent process of narrative creation as opposed to questing for empirical truth (Rowlinson et al., 2009).

Critical reflexivity is also necessary - the act of questioning assumptions about knowledge. In this context this means viewing representations of "common sense" concepts of management and questioning how and why these ideas have developed (Jacques, 1996, 7). A reflexive 
researcher acknowledges that it is impossible to take a genuinely neutral ideological stance, and therefore also acknowledges and embraces critique of their own ideas.

\section{Why the historic turn is valuable}

Clark and Rowlinson (2004) claim that surface-level historical parables with a clear and easily applicable message are too often offered as facts rather than opinions. A recent example of utilising the 'historic turn' to question such narratives is Hassard's (2012) counter-history of the famous 1920s Hawthorne studies. These studies are a staple historical concept in organisational behaviour based on the innovation of Harvard Business School professor Elton Mayo and the observations made during his research at the Western Electric Company's Hawthorne Works (as represented in Roethlisberger \& Dickson, 1939). The generally accepted story is that Mayo arrived at the Works and experimented with factors such as group size, lighting, break times, and types of employee supervision. This is framed as a significant discovery showing that paying attention to various overall worker needs would improve productivity. In this story, Mayo is vital in moving management away from the previous 'scientific' approach concerned largely with output, enabling a pivotal shift towards a 'human relations' approach valuing the worker. But Hassard's critical study looks closely at the prior situation at the Hawthorne Works and argues that a human relations philosophy focusing on employee well-being could in fact be observed before Mayo's arrival. This counter-history indicates that the allegedly revolutionary nature of Mayo's work is more complex and contestable than organisational behaviourists may like to admit.

An important early instance of this type of deconstruction is Wrege and Perroni's (1974) work regarding perceived misconceptions about the importance of Frederick Taylor's early experiments in scientific management. They expressed concern at textbooks and articles for sixty years citing Taylor's study of physical labourers loading pig-iron at the Bethlehem Iron Company in the late $19^{\text {th }}$ century as an example of his revolutionary contributions to management. Wrege and Perroni studied historical documents and found that the story commonly presented did not match these documents. The story often told is that Taylor developed standardised methods to increase productivity, including introducing rest periods, and paying workers for work produced rather than time spent. He touted the effectiveness of this "piece-rate" payment approach as he claimed that monetary rewards were the key incentive to productivity increases (Moorhead \& Griffin, 1992, 10-11). 
Wrege and Perroni claimed that Taylor's story consistently changed, offering three alternative accounts of the study in 1901, 1903 and 1911. This 1911 story was the one generally picked up as fact, but the evidence of these earlier versions indicate that it was the result of over ten years of tinkering, more fiction than fact. The paper concluded that Taylor knowingly fabricated aspects of his story on the basis that the end justified the means. Wrege and Perroni claimed that their investigation was important because Taylor's system of management is such a fundamental aspect of management studies, "which has deeply affected work relationships to this day" (Wrege \& Perroni, 1974, 11). After telling this standard version of the Taylor story, Moorhead and Griffin's (1992) textbook does point to Wrege and Perroni's critical analysis. This indicates a willingness amongst textbook authors to include well-argued critical perspectives disputing previously accepted narratives. Wrege and Perroni suggested that "some of management history may require some reevaluation" $(1974,26)$, and that their Taylor critique could be taken as a model of this sort of reevaluation. It is a fair suggestion, and Godfrey et al. (2016) discuss the study as important for paving the way for the more recent wave of critical analyses of history, such as Hassard's Mayo critique. This claim is appropriate, as the 1974 paper is notable for direct criticism of the usual representation of early management experiments, and a concern that uncritically teaching one version of history at the expense of others could negatively affect students. Providing them with a version of a "great man" story where research can easily reveal that the veracity of the tale is questionable, but claiming it as straightforward 'truth', is needlessly limiting and underestimates students. The work of Wrege and Perroni, and the subsequent inclusion of their argument in textbook discussions of Frederick Taylor, expands the discussion without burying the previous story. Providing a counter-argument demonstrates to students the value of questioning narratives that are presented.

A critical approach can also illuminate imbalances of power. Some voices are accepted as knowledge, while others are "silenced, marginalised or excluded" (Fletcher et al., 2009, 82). Many studies, especially from feminist and post-colonial contexts, have pointed out that "the core values of science correspond more closely to the core values of white, Western males of a certain historical period than they do to other people and other times" (Jacques, 1996, 17). Accepting this principle would be difficult from a reconstructionist perspective. This would mean accepting the historian's power to shape the narrative, imprinting their biases upon it. Deconstructionist theorists already accept that history is just a form of representation. Deconstructionism can start to actively redress social imbalances, seeking out the more 
marginalised corners of the past, or providing a new interpretation of a well-known event or movement.

Critical management studies have examined the mainstream representation of pivotal figures in management history like Abraham Maslow, such as the marginalisation of the Cold War's political context on his work (Cooke et al., 2005) or the inaccuracy of textbooks aligning Maslow's hierarchy of needs concept with a prescriptive 'managerialist' perspective for improving workers' productivity, given his work's vast range of positions, including a sympathy for radical humanism (Dye et al., 2005). Bridgman et al. (2019) have pointed out that the ubiquitous pyramid representation of Maslow's hierarchy was not in fact created by Maslow. They argue that this graphic decision is a problematic and reductive representation of his original ideas. Cooke (1999) examines evidence of leftist politics of the social psychologist and change theorist Kurt Lewin, claiming that they are largely ignored, while Cummings and Bridgman (2011) investigate mainstream representation of Max Weber as bureaucratically obsessed, which conveniently forgets his well-documented scepticism about the topic.

As well as deconstructing the stories told about famous historical figures, a critical look at history can help to combat tendencies towards what Clark and Rowlinson $(2004,335)$ called "hagiography rather than historiography", where hero leaders are worshipped as visionaries. Founder-centred corporate histories uphold the status quo view of the importance of a single heroic figure because they present their learnings from history as self-evident (Rowlinson et al., 2014). Criticising this does not mean rejecting the importance of the work of these figures, but the fact that $20^{\text {th }}$ century heroes of management are almost exclusively white males deserves to be questioned. Critical approaches to management history can take a feminist position, such as Williams and Mills (2017) discussing the near absence from organisational history of Frances Perkins, a key figure in Franklin Roosevelt's 'New Deal', and arguing that her "ethic of care" towards workers is worth more consideration today. Another focus of criticism is the marginalisation of African-American innovations, including prominent black businessmen like Charles Clinton Spaulding (Prieto \& Phipps, 2016; 2019), as well as Cooke's (2003) claims that the origins of modern practices and theories can be traced to American cotton plantations' use of slave labour in the $19^{\text {th }}$ century. Cooke argued that management theorists have deliberately obscured this uncomfortable fact. This sort of study is valuable for questioning the biases in modern management studies and arguing that an understanding of history is pivotal, even when it is complex or unpleasant. These critical 
studies have varying aims and methodologies but are united by a sense of deconstructionism. They look at popular narratives about famous historical figures in management, and examine, through close attention to historical sources, how else these people can be represented. Drawing attention to details that have been overlooked by the usual textbook narratives helps to enrich the story - this particular study asks how else the groupthink story can be told.

\section{Relevance to management education}

Where history is utilised in organisation studies, it is often to present modern management ideas as more enlightened or complex versions of past theories. The representations of historical figures like Mayo and Taylor discussed earlier exemplify this well. Critical authors like Clegg and Lounsbury (2009) argue that common representations of such figures involve simplification or distortion of their work to establish a boundary around the management discipline - a boundary maintained by textbook authors. Each textbook author plays an important and active role in selecting and presenting data. This is a subjective process in which "textbook authors are not passive conduits but active participants in the creation of a hegemonic discourse" (Mir, 2003, 737). Critical writers Grant and Mills (2006) perceive this discourse to be managerialist. They claim that textbooks focus on and elevate the manager's role and support hierarchical power relations as legitimate. Presenting such an ideology without significantly questioning it has a purpose - it is presented as objective truth. Critical theorists have argued that these reconstructionist methods have obscured political perspectives (among others). Cooke (1999) makes a case for management studies incorporating concepts developed by the political left while minimising this political context in their modern representations of the concepts.

Management historians Wren and Bedeian $(2009,3)$ discuss the neglect of management history in most business schools, claiming that even where it is taught it generally lacks depth, preventing the informed and wider understanding gained from studying multiple perspectives. But research and teaching tends to focus on structure and stability, essentially asking questions like "how do organisations/ideas stay successful?" Aldrich and Ruef (2006, 3) claimed that this focus can blind scholars to the possibility of instead examining change and instability - asking why ideas are formed and how and why they change and develop. This is best achieved by returning to ideas' origins and considering them within their relevant social contexts. Textbooks tend to decontextualize events in an attempt to make them more 
generalisable as lessons, but often this position "in which organizations appear uprooted from their sociocultural environments" (Maclean et al., 2016, 618) omits the more interesting and complex aspects of human behaviour. Alternatively, a deconstructionist approach can show that modern management concepts are embedded in the historical processes that have shaped them (Suddaby et al., 2014).

A more historical perspective will assist management studies in attempting to "provide a critically reflective vision of the good society" (Jacques, 1996, 9). Business schools' aversion to more subjective historical studies stems from the history of the business school as an institution, specifically the need to present management as a science. Part of this involved a heavy focus on objectivity, allowing managerial science to be removed from questions of politics and bias. An important instigator in the move towards this focus in American institutions was the Gordon and Howell (1959) report on the state of business schools. They concluded that more objectivity was required, and teaching students a new model of business training based on science could "allow managers to make decisions solely on analytical and rational grounds, without recourse to fuzzy notions such as intuition or judgment" (Khurana, 2007, 271). However, I would be remiss to mention these reports without noting McLaren's (2019) critical analysis which points out that acting as if this report were the only catalyst for the change of management education is an oversimplification. But McLaren did agree with the general notion that a mid-century shift toward objectivity could be witnessed.

\section{The role of textbooks in limiting historical engagement}

There is an argument in recent critical literature that management textbooks, reflecting the broader field's general historical antipathy, play a part in narrowing readers' understanding of management history (Bridgman et al., 2019). The critical perspective on the mainstream management textbook is summed up well by Alvesson and Willmott $(1996,24)$ : "Management is represented as a set of techniques that are functionally necessary for the smooth running of systems. Instead of confronting the positioning of management with capitalist relations of production, the focus is upon the design of systems rather than their effects, and upon the techniques that professional managers should acquire to ensure their smooth operation". If the notion is accepted that any representation of history involves a narrative, then a textbook's narrative is often deliberately simplified to minimise contradictions or complexities. Why is this the case? One of the best-selling and most 
influential textbook authors, Stephen Robbins, has claimed that "the classical material in management textbooks has little value to today's students" (1997, xvii). So if 'classical material' is not perceived to be valuable, what is? In an article in Journal of Management Education entitled 'Management textbooks as propaganda' (Cameron et al., 2003), Robbins provides an insight, perceiving his textbooks as supporting an ideology that he attributes to most other organisational behaviour textbooks - "a managerial perspective. This reflects the market - business schools. We need to genuflect to the Gods of productivity, efficiency, goals, etc." (714). This implies that an attempt to change the focus of business textbooks will be futile without this change also occurring within the market that they service - business schools. In the relatively rare instances where educators do approach history, Clark and Rowlinson (1997) believe that teachers present themselves as offering facts rather than opinions in their view of history. The three other prominent textbook authors interviewed in the 2003 paper agreed with Robbins regarding the need to reflect a managerial ideology, but a point is also made about "the role of publishers and faculty members in limiting the amount of textbook innovation that is possible" (727). This means that authors are not entirely to blame, but the paper does conclude that the authors are mostly driven by a sense of conservatism. Their textbook work has been very successful, so it is a status quo that they do not particularly wish to disrupt. This status quo is also maintained by business historians taking a non-forthcoming stance on sharing their methods, seeing this as needless justification, and even "bad craftsmanship" (Bucheli \& Wadhwani, 2014, 20), like a magician exposing how their tricks are performed. This is because the reconstructionist view assumes that it is telling the most accurate story possible - so why justify this? (Clark \& Rowlinson, 1997, 336). And this motivates the disinclination to become bogged down in methodology: the end result is the focus.

As a part of their desire for simplicity, textbooks often rush through the complex history of management. Dye et al. $(2005,1391)$ believe that this has significantly contributed to "the perception of mainstream management theory as narrowly focused and managerialist". Carroll et al. $(2018,175)$ recommend a future for textbooks "leaving sufficient space between the lines for critical interpretation by educators or students to be developed". The past can reveal a different way of doing things (Bucheli \& Wadhwani, 2014). In the research empiricism-focused present (reflected in the modern textbook), it is valuable to acknowledge the possible significance of insights from another era (Bridgman et al., 2019, 93). Ultimately the value of attempts to examine and deconstruct management history lies in the hope that 
facilitating students thinking critically about management history and its construction will lead to a more creative future for the field, including a more historically-engaged approach to textbooks and the possibility of encouraging students to read the original texts (Cummings \& Bridgman, 2011; 2016).

\section{My groupthink narrative}

The deconstructionist approach taken here will arrive at a considered conclusion about groupthink and how it has evolved, in order to make informed criticisms of its representation and offer suggestions for how groupthink can be presented in the future. Much of the body of this thesis works to create a specific story, a mostly chronological account of the parallel developments of Whyte and Janis' career. But throughout the construction of this work, there is a constant awareness that this is not the only story. Part of my argument discusses the state of management writing and criticism in the 1950s, but I endeavour never to conflate this with the 1950s as a whole - the decade can be represented in countless distinct ways. Even within my specific niche of management writing, the same information could be represented in numerous permutations. My story that convinces me; if it did not, the existence of this thesis would be questionable. But it is not the story. This chapter has explored the ways that critical history can be represented. The task is now to further explore the best way of carrying out this specific historical study into groupthink in order to create a compelling and convincing narrative. 


\section{CHAPTER 3 - Methodology: How to Deconstruct History}

Having explored the literature of the critical studies to which I intend to contribute, it is important to set out how exactly this study has been done. This thesis is not one that constructs new data by the means of methods like surveys or field research. Therefore a specific methodology must be followed to give my research a specific scope. This enabled me to work out what sort of data to be searching for, and more importantly what to do with it. This chapter will establish my Foucauldian approach, driven by a desire to ascertain where power is held in management learning, and what can be ascertained about the current status quo representations of management ideas. The previous chapter explored the calls to integrate historical research into organisational learning, and here I will articulate how exactly I will do this. This means setting out the examples of the type of data needed (and why) and articulating the method of textbook analysis as a valid primary methodology for gathering the data on the history of groupthink.

\section{A Foucauldian approach}

The deconstructionist historian Keith Jenkins $(1991,69)$ opined that everybody has some sort of agenda or bias informing their study and the methods with which they carry it out. Even if only implicitly, no historical criticism can be without a theoretical position. I accept the need to define such a position and will consciously employ a Foucauldian methodological approach inspired by French philosopher and “counter-historian” Michel Foucault's (1980) critical historical approach. This involved questioning the accuracy of previously accepted groupings and divisions in the organisation of ideas. A well-known example of this work is his History of Sexuality (1978), where Foucault examined $20^{\text {th }}$ century perceptions of the Victorian era as a time of prudishness and repression, certainly in comparison to the much more liberated present. But Foucault countered this assumption, and therefore questioned the motives of those who disseminated such information. They were keen to portray a sense of progress and increased moral liberalism, while Foucault offered an alternative narrative. After conducting a historical study he made a case for the Victorians as in many ways more liberated compared to their modern counterparts.

A Foucauldian approach, then, means not simply accepting what one is told about history, even if is it a vastly dominant narrative accepted as fact by the majority. It involves a process of perceiving history as a device for creating new connections between texts and "making 
discoveries far more profound than simply collecting specific facts" (Radford \& Radford, $2005,73)$. An important aspect of Foucauldian study is analysing the balance of power. Some people deliberately act towards shaping the representation of knowledge to promote their agenda or beliefs, while other contributions are unconscious (Jäger \& Maier, 2016, 118) - the result of people perpetuating their assumptions. The point here is that objective knowledge cannot really exist, as what people accept as knowledge will differ wildly. A critical analysis of history seeks to discover where power is concentrated to address which methods and ideas are "sanctioned as authoritative forms of knowledge" (Alvesson \& Willmott, 1996, 49), and to determine who benefits from these accepted narratives. Foucault was interested in ideas that resisted the accepted primary discourse, and often focused on marginalised groups to determine competing forms of knowledge (Green \& Troup, 2016, 294). Part of doing a Foucauldian critical historical study is accepting that an attempt to narrate and describe history is always to some extent an attempt to exert power (Leblebici \& Shah, 2004). Foucault wanted to represent "the history of the present", where the starting point for a historical study is a diagnosis of the contemporary situation. The ensuing study attempts to locate where an idea or manifestation of power originated and how it evolved. This does not mean "project[ing] current meaning back into history" (Dreyfus \& Rabinow, 1982, 119) which is a difficult tightrope to walk when explicitly starting with a contemporary problem. One can begin a study based on a contemporary point of interest and engage in a historical analysis of the relevant trends, but care must be taken to continue to view the past as distinct from the present. This "history of the present" idea is relevant to my own study as an important starting point for the thesis was that most modern textbooks attribute groupthink to Irving Janis.

\section{Viewing management history differently}

Embracing Foucault's methodology, and the challenge of viewing the past differently, means in this context asking why textbooks and articles treat history as they do, and questioning whether this is a good or useful representation of events (Cummings et al., 2017, 36), and whose interests are being served, while acknowledging that perceptions of 'good' and 'useful' vary. This methodology involves breaking free from deeply entrenched views usually accepted as fact and instead making "alternative refigurings" of history (Jenkins, 2003, 57). The resulting counter-history that I present here will make no grand claims for objective correctness, but offering choices is important to prevent an ideological monopoly. A counter- 
history based on Foucault's approach means challenging what is "already known" by questioning historical assumptions in order to "free thought from what it silently thinks, and so enable it to think differently" (Foucault, 1985, 9). My counter-history will present Whyte's ideas and contrast them with what is "already known" to allow a discussion to take place. An important aspect of Foucault-inspired research is an attempt to bring increased attention to people or events from the past which conventional histories have overlooked, forgotten or misrepresented (Bridgman et al., 2016). With the acceptance that history is more questionable than one may have previously assumed, a greater ability to investigate alternative ideas can be achieved.

\section{Textbook analysis}

How will I go about achieving my Foucauldian historical analysis more specifically? Bryman and Bell (2011) discuss historical analysis in terms of the study of "documents and other artefacts that can be used to trace the history of an organization or an industry" (564). As my task involves analysing the representation of groupthink and its changes over the years, textbooks are an appropriate resource to form the bulk of the source documents. This is a rare form of study, with Watson (1997) pointing out that texts have rarely been treated as "comprising self-contained data in themselves" (85). Archival analysis has been criticised as "not properly a method of empirical organizational research because data and information are collected, rather than being directly generated in the course of the organizational research" (Strati, 2000, 133-134). Qualitative researchers tend to prefer primary data that they have constructed, via interviews and similar methods. (Rowlinson et al., 2014). But this would be largely inappropriate in this case. Carrying out a survey-based qualitative study to gauge current opinions about groupthink and the role of textbooks and universities could provide a diagnosis of groupthink in 2020. But it would not give adequate answers for how we arrived at this point. When did Janis overtake Whyte in public consciousness? How did textbooks change through the years? For questions like these, a consciously historical study is necessary.

Bryman and Bell (2011) discuss how documents are "significant for what they are supposed to accomplish and who they are written for" (559). This will be a key consideration throughout the process, where the documents will often be textbooks. It must be at the forefront of all analysis that the general intention of management textbooks is to educate students about aspects of the fields of management and organisational behaviour. But this 
consideration must not go too far. Jenkins (1991) points out that even texts regarded by historians as 'primary' are themselves only representations of the past, as told by their authors. Green and Troup $(2016,291)$ note that authorial intent and the context in which a text was written is not necessarily indicative of a text's meaning. We are only left with a text. This does not mean that authorial intent and context are irrelevant. Searching for clues to indicate these can be useful, but these clues again will come from texts, with their own unique assumptions and contexts.

\section{The value of textbook study}

Textbooks provide a collection of knowledge about the foundations of management studies and inform students' behavior as future practitioners (Stambaugh \& Trank, 2010). Textbooks play an important role in creating and maintaining disciplinary boundaries. Through decisions about inclusion and exclusion, as well as the way that content is organised and presented, textbooks constitute and maintain the object of their study (Harding, 2003). Greater critical research into textbooks could provide an insight into how authors "rhetorically position their ideas to either support or undermine dominant views" (Stambaugh \& Trank, 2010, 676). It could also allow more flexibility and openness in integrating newer research, or reappraising and reevaluating older research. This could be achieved more thoroughly by regularly consulting researchers as well as students - the textbooks' main target market. Stambaugh and Trank $(2010,677)$ note that "we generally expect an "implications for practice" section at the end of our journal articles, but do not require an "implications for teaching section"”. The point is reasonable, as fundamentally the result of teaching manifests itself in management practice: they are largely inextricable. If journals did include a more specific analysis of how research can be directly applied to management at the teaching level, a greater complexity could be built into teaching. It would be more responsive and reflect the cultural and social environment to a greater extent. A management textbook analysis with an explicitly historical interest is Bell and Taylor's (2013) study of popular $21^{\text {st }}$ century textbooks, finding very minimal references to history. Perlmutter $(1997,68)$ agreed that "the textbook vision of society is homogenized and sanitized to reduce the risk of controversy". The impulse behind this is clear - accessibility is important, but could this sanitisation in fact limit the alleged goal of student learning? A question worth asking is why management textbooks represent theories the way that they do. Common responses like "it is the best way of teaching students" or "because it best represents the work of the original theorists" are not necessarily 
enough. My research seeks to provide a counter-argument to the assumption that the minimisation of history is the best and most representative way of teaching management.

\section{Data collection: Constructing the corpus}

Textbooks here are the primary data as ultimately the examination of groupthink will act as an example of the widely accepted methods of presenting management ideas within textbooks.

Data has been collected from an examination of a wide range of textbooks and articles:

1. A sample of post-1972 textbooks: In order to get an insight into patterns or themes regarding the representation of groupthink after Janis' 1972 Victims of Groupthinkto whom it is attributed is important (do any books recognise Whyte?), but so is the usage of the theory. The representation of groupthink in these books has been examined to determine how it is framed - as a tool for managers to oversee their groups more closely? As an issue facing society, or only select small groups?

2. Pre-1970s textbooks: Searching specifically for any references to groupthink, or to Whyte, or to Janis. Before Janis' article, what was said about groupthink? Are there common themes in the representation of Whyte's work?

3. Research articles about groupthink (1970s-present): To survey the general academic or scientific perspectives on Janis' work, determining the nature of tests that have been done on the theory, and cataloguing the results. With a particular interest in the extent of empirical testing.

4. Any other texts of note: A much less structured set of sources, but still essential any article or book discussing Whyte or Janis or their theories, or group dynamics generally. This helps to provide context, and includes opinion pieces, obituaries, and Whyte and Janis' work in other fields.

After collecting data, the analysis process involved the creation of an alternative history of groupthink, based on empirical data but taking a deconstructive approach, questioning the common conception of groupthink and presenting the historical data within a narrative that 
seeks to provide a convincing possible explanation of the modern absence of Whyte relative to Janis regarding the conception of groupthink. From a Foucauldian perspective, "datadriven research provides only data" (Jacques, 1996, 190). To inform debate and use historical data to create a dialogue, data should be viewed in an interpretative way. This involves a process of qualitative content analysis, searching for repeated themes in the relevant sources (Bryman \& Bell, 2011). What is unsaid in the sources may be equally as important as their content (Decker, 2013). Finding a textbook that references neither Janis nor Whyte could indicate a lack of interest in conformity. Of course, it could also indicate a lack of interest in Janis or Whyte, or a lack of knowledge of their theories. Interpretations and assumptions must be made in this process, but they should be done with attentiveness to the facts. Data is not objective, but it can support some conclusions more clearly and convincingly than others.

\section{Using individual textbooks to indicate trends}

An important note should be made about individual textbooks discussed in this study. Writing a textbook, and providing an accessible overview of a complex field, is not an easy job. Simplification is to some extent mandatory. Trying to capture every nuance and historical variation of theories would result in a massive (and confusing) tome, likely alienating the intended readers. Following the lead of Fougère and Moulettes (2011), when specific extracts are chosen it is to indicate the relevant trends and patterns. The intention, even when critical of the content, is not to criticise individual textbook authors, but is part of an attempt to analyse the "power effects [which are]...the result of a powerful discourse that is reproduced" (Fougère \& Moulettes, 2011, 6). Discourse here refers to the overall trends in management discussions and debates about groupthink, as well as more broadly how management scholarship views and represents its concepts and history. This is particularly pertinent here because textbooks' descriptions of conceptual content will not always originate from the original sources. There is a likelihood of borrowing representations of concepts from the established 'canon' of management textbooks, which is why the same concepts appear across so many different books. The phenomenon of multiple editions of textbooks is also a useful guide to some of the changing perceptions during the many decades of the 'modern' management textbook. It is common that a close study of changing textbooks can reveal significant inclusions and exclusions reflecting to some extent the context of their publication. Even the smallest change to a textbook's wording could reveal something of significance about the changing mindsets of their authors as society itself changes. 


\section{Representing data: Generalisations and representations}

The way that this data will be represented is also important. Jordanova (2006) makes an argument regarding the need to classify the past in some way in order to have any hope of managing a representation of it, noting that phrases like 'contemporary history' are popular, but could represent a wide scope of possible historical times. There is also the question of an increasingly large appreciation of the need for multi-factorial explanations of history rather than emphasising single causes that produce a clear chain of events. This means considering various possible factors behind an event. Applying these concepts to this thesis means being clear about periods. In this case, the formulation of concepts like 'management' and the 'modern textbook' occur in the 1950s to 1970 s, while 'recent' history generally represents developments from the 1990s to the 2020s. Still, care has been taken to avoid excessive generalisation, and the scope of history being dealt with is small enough that I can usually be specific about a decade or a year, rather than having to use an umbrella term to try to arbitrarily characterise a period. The notion of multi-factorial explanations is also pertinent to my data collection and its subsequent analysis. The goal was not to make a definitive discovery of why groupthink is no longer credited to Whyte. Multiple factors are analysed and explored. Stambaugh and Trank $(2010,675)$ noted that a limitation of their own textbook study was the struggle to find a representative sample of texts, noting that 'bestsellers' as a metric is hard to truly gauge, partially due to the lack of data. They were also unable to look at an international sample. My study is more wide-ranging than their North Americanfocused sample, but the issue is still a pertinent one. Part of the motivation for critical study is to give a voice to the underrepresented, but regarding a textbook sample, the fact that most textbooks are from a Western perspective is unavoidable. Thankfully in this study this is the perspective that is mostly being critically analysed, and of course Whyte and Janis' studies were conducted with a primarily Western perspective - North America is the primary focus for both men, though both authors suggest a wider possible applicability.

Awareness of my methodology is essential for the analysis that follows. My research centres around the Foucauldian principle of applying a deconstructionist view to history and questioning all assumptions and taken-for-granted knowledge. This enables the questioning of the definition of groupthink (as a Janis creation) that is commonly offered. I ask why this is the usual interpretation, and the method for doing this is a qualitative historical study with textbooks as the primary form of data. I will not create new data in the form of surveys, 
because my research is about creating a cohesive narrative to try to explain what has happened between 1952 and 2020 to minimise William H. Whyte's contribution to groupthink. This will first involve presenting a counter-history informed by deconstructionist methodology. Unlike the currently accepted form of history where Irving Janis is central, this counter-history will begin with the first instance of Whyte writing about groupthink and will explore subsequent representations of the man's work, creating a form of history that highlights the fading of Whyte from public perception while also making a case for the recognition of his contribution to groupthink. This can illustrate the significant value that his ideas could still hold today. 


\section{CHAPTER 4 - Groupthink Counter-History: William H. Whyte, Jr.}

"Some people, having carried to an extreme their interest in groups, begin to worship the group. This philosophy has been termed groupthink and critically described by W. H. Whyte Jr"

(Davis, 1957, 283-284)

In this chapter, following the methodology previously outlined, I will argue for a version of management history in which William $\mathrm{H}$. Whyte Jr. played a central role in the prominent and popular 1950s business literature taking a strong interest in the dangers of conformity and the threat of increasingly large corporations. This will help to demonstrate why it is important to remember these times and assess their continued relevance today to enable a more critical view of management. Developing the ideas discussed in his "Groupthink" article in Fortune magazine, Whyte's 1952 book Is Anybody Listening? and his better-remembered The Organization Man (1956) caused a commercial and critical stir, forming an important part of a genre of social criticism of American post-war society amidst increasing dominance of group dynamics. This section presents a counter-history of the origins of groupthink, where the concept arises as a device to hold corporate America to account, as well as to question the management techniques propagated by social scientists and tertiary educators.

\section{Whyte's early career and groupthink}

William H. Whyte Jr. likely would not have described himself as a radical. He was "straight Establishment and a card-carrying, socially conservative member of the American gentleman class" (Hodgson, 1999). Born in 1917 in West Chester, Pennsylvania, Whyte attended boarding school during the Great Depression, and the 1929 stock market crash had a significant impact on a 12-year old Whyte. He witnessed the profound impact of its aftermath on his peers, entering the workforce in an uncertain new world. Job security was now particularly critical, driving people into the arms of corporations as a matter of necessity rather than adoration (Polman, 1987). He graduated from Princeton in 1939 and took a job at the Vick Chemical Company selling their products, including Vick's VapoRub (Nocera, 2002). He joined the Marines and became an intelligence officer and at the end of the war began writing for the popular business magazine Fortune (Kaufman, 1999). Around this time the magazine had developed an interest in critically exploring connections between 
corporations and society, with Whyte playing a leading role in developing the magazine in this direction (Nocera, 2002).

In 1952, Fortune published Whyte's article "Groupthink" as part of the magazine's Communication series. He wrote of his concern at the increasing consensus that the individual had no meaning except as a group member. To describe this philosophy, he introduced the term groupthink; "a coinage - and, admittedly, a loaded one" (1952a, 2), and provides a working definition:

We are not talking about mere instinctive conformity - it is, after all, a perennial failing of mankind. What we are talking about is a rationalized conformity - an open, articulate philosophy which holds that group values are not only expedient but right and good as well. (1952a, 2)

He created the image of a pleasant treadmill. While young workers were aware that they were trapped by organisations and felt impotent as individuals, they also believed that they needed the group for any hope of security in their emotional wellbeing. Whyte pointed to popular culture and literature to illustrate his point, referencing a Fortune analysis of magazine fiction plots in 1935-36 compared with 1950-51, and finding that the protagonists of the latter years were markedly more submissive. He believed that this trend reflected a wider tendency to turn away from independence towards submission. In addition to fiction, this message was translated by its disciples in hundreds of lecture halls and papers" (6), creating a purposeful and substantial movement pushing groupthink's ideology. While Whyte was wary of offering a complete explanation for the origins of the groupthink trend, he pointed to the role of social engineers positioning themselves as a trained elite, aided by a "blind faith in scientism" (10) to defend this turn towards conformity. It was to some extent a deliberate pushing of an ideology, supported by propaganda. The overall effect was to encourage submission and obedience to a status quo based on group values, and ultimately "freedom from moral choice" (10). Whyte did not provide a definitive solution to his concerns. He claimed that a return to "rugged individualism" (14) was not his intention. But he did call for a renewed respect for the individual in the hope of retaining ethical fortitude and autonomy. Some specific suggestions were offered, including a proposal that corporations consciously encourage and accommodate dissent, as well as a revival of the humanities. However, his conclusion was that "possible approaches to a problem so fundamental cannot easily be spelled out" (14). 
Later that year, Whyte published a book called Is Anybody Listening? A pre-publication advertisement of the book in the Wall Street Journal (Simon and Schuster, 1952) highlighted a desire to hold American industry to account, accusing large organizations of selling the 'American Way of Life', particularly through the "religion of Conformity and Group-think, fostered in corporation employees". The advert's promise to make "some of American Industry's Big Brass - and little brass - quite angry" promised a deliberately provocative account. Is Anybody Listening? saw Whyte aiming more specifically at systemic issues in American business. The book encouraged readers to lie in personality tests, seeing them as an invasion of privacy and a cynical attempt to create homogeneity. It also criticised attempts to promote 'Free Enterprise' as a desirable ideology, with American businesses eager to rebadge capitalism, ensuring that it remained palatable (Gable, 1953, 264). Employers were advised, based on extensive research, that 'free enterprise' was likelier to be positively received by workers than 'capitalism' (Beder, 2006, 58).

"Groupthink" is the book's final chapter. While the body of the text does not use the term, it deals with similar issues to those explored in the Fortune article, with Whyte concerned about the repurposing of old concepts of individualism to justify and promote the opposite submission to groups. The burgeoning field of human relations was again targeted, and Whyte's 1952 groupthink criticism was "made at a time when some business organizations were conducting none too subtle anti-union campaigns of economic education and communications" (Foltman, 1964, 655). He claimed that social scientists believed that "by subordinating oneself to the group, one becomes an individual" (1952b, 235). Whyte envisaged potentially excellent individuals opting instead for "easy harmony" $(1952 b, 237)$ to appease the group and avoid disruption, with the effect that innovation and creativity are stifled. Prominent management theorist Chris Argyris (1957) praised the surveys conducted by Fortune into the lack of enthusiasm for the free enterprise system despite significant and expensive promotions, as well as Whyte's illustration of “top management's anxiety over the gap in communication" (Argyris, 1957, 141) in their attempts to sell this ideology. Argyris posited that "these programs are primarily related to management's dominant assumptions that the employees are lazy and apathetic" (142). Argyris did not believe that this was the case, and neither did Whyte. He thought such blatant propaganda underestimated the intelligence of American workers. Whyte also balked at the cost of this barrage of information, with public relations experts utilising "magazines, bulletin boards, pamphlets, meetings and advertisements" (Whyte, 1952b, 58) to 'sell' their message. 


\section{Reception to groupthink and Is Anybody Listening?}

Whyte's writing on groupthink established him as an authority on management in the 1950s. Hoban $(1953,247)$ expressed admiration of Whyte's "incisive" examination of status as a barrier to communication. The Far Eastern Survey described Whyte's groupthink article as "required reading" (Dean, 1952, 41) in dealing with international affairs. Elsewhere it was described as ideal reading for introductory sociological studies (McClung Lee, 1953). A review of Is Anybody Listening? shortly after its publication in The Public Opinion Quarterly praised the book as "interesting and provocative" (Bernstein, 1952, 299), mentioning the groupthink philosophy by name and concluding that corporations adopt "a contemptuous, belittling attitude" (299) toward the individual. Childs and Cater (1954) stressed that Whyte was not anti-business. They perceived his work as being more focused on "the oversimplified presentation" (118) of the free enterprise system. Whyte defended his claims and added that while people may discuss ideas in groups, "they think only as individuals" (Foell, 1965, 9). Such a statement casts some light over the possible implications of the term 'groupthink' that this is an actively unnatural form of thought. The concept also had appeal beyond the world of human relations, with religious journals (Thomas, 1957; Eenigenburg, 1961) expressing interest in Whyte framing groupthink as being worshipped as fervently as if it were a religion. Eenigenburg $(1961,13)$ posited that if groupthink "is god, the Church is a kind of refuge for the personal life". A textbook by Byrt (1980) later made an opposing claim, that churches regularly engage in groupthink.

Whyte's ideas about groupthink were picked up by a newly emergent textbook genre, often mentioning the concept by name. Authors referencing Is Anybody Listening? emphasised the role played by large organisations in actively pushing the importance for those seeking promotion of being an "expert group member" (Coates \& Pellegrin, 1957, 211), and the organisation's increasing demands on their employees' family lives (Litwak, 1960). Vance's (1959) textbook Industrial Administration stressed the importance of groupthink as a contribution, expressing concern about growing organizations needing to appeal to increasing numbers of employees, and the corresponding "debilitating reliance" (162) on groups to perform most decision making. Harold Leavitt's first edition of Managerial Psychology (1958) noted a "growing vanguard of 'group-thinkers"” (190) and includes a reference to Whyte. These 'group-thinkers', Leavitt argues, have an "almost mystical faith" (190) in committees. Leavitt comes to a similar conclusion to Whyte regarding the new perception of 
small problem-solving groups as a major managerial tool. He notes that phrases like 'group dynamics' can be useful but are too often used as basic rules of thumb that can help groups to solve any problem. Leavitt notes the danger of the notion that groups must be happy to be productive, and pinpoints happiness as a precursor to conformity.

While the increasing emphasis on group dynamics within this field had many high-profile critics, including William $\mathrm{H}$. Whyte, there were also those who leapt to its defense. This created a vibrant debate within scholarly and practitioner communities. Robert Tannenbaum (1959), writing for California Management Review, disagreed somewhat with Whyte.

Despite calling him a "competent observer" (55) and comparing his ideas with contemporary group critics David Riesman and Malcolm P. McNair, Tannenbaum claimed that while much academic attention focuses on groups, this ultimately serves to determine their effect on the individual. Golembiewski $(1965,232)$ claimed that Whyte's groupthink fears were valid, but in extremis only. He noted that group relations should not be neglected. Keltner $(1957,5)$ referred to groupthink by name only to quickly dismiss it. He claimed that individual thinking, however strong, would only be of practical use when utilised in teamwork.

\section{The organisation man}

Whyte's writing in Fortune on groupthink and conformity laid the foundation for the work he is best-known for, The Organization Man (1956). This book does not mention the term 'groupthink'. He preferred the 'social ethic', claiming that this had displaced the individualist 'Protestant ethic'. He attributed three features to the social ethic: a belief in the group as a source of creativity; a belief in belongingness as the ultimate need of the individual; and a belief in the application of science to achieve this belongingness. The connection to groupthink is very clear, as Whyte's Fortune article had also attributed three main features to groupthink: relativity of morals and ethics; a belief in the importance of attitudes and behavior allowing for group harmony; and the application of scientific techniques. The creativity and belongingness aspects of the social ethic are more specific branches of the "attitudes and behavior" groupthink idea, while the criticism of blind faith in scientific techniques remains virtually unchanged. If this was an attempt to relaunch the basic theory given that groupthink had not been a massive popular hit, it was a success, with The Organization Man selling more than two million copies. A close examination of this book, and the response to it, must form a significant part of my analysis. It is directly relevant because it is virtually the same theory, and it is important to explore just how widespread the 
idea became. This can provide direct evidence that Whyte's groupthink work has not been forgotten, but has just been renamed, hiding in plain sight.

Upon the release of The Organization Man, C. Wright Mills described the book as "first rate" and Whyte's "description of the ethos of the technician in America today among the best available" $(1956 b, 6)$. A textbook by Tannenbaum et al. $(1961,49)$ claimed that it perhaps best exemplified the wealth of 1950s academic writing concerning conformity, also citing McNair, Riesman and Erich Fromm in a discussion of increased "groupy" alignment, though Tannenbaum et al. wondered whether this would necessarily destroy individual uniqueness. While writing the book, Whyte often considered George Orwell's dystopian novel 1984, and protagonist Winston Smith's final declaration that he loves Big Brother, the totalitarian government's figurehead. He thought that this need for total conformity was reminiscent of what large 1950s organizations were doing (Polman, 1987). This connection between Whyte's and Orwell's work was noted by other writers. McClung Lee (1953) claimed that “one should read George Orwell's 1984 before turning to Is Anybody Listening? because of the many borrowings of Orwell terminology" (437). While McClung Lee does not specify the terminology to which he refers, 'groupthink' could stem from Orwell's 'doublethink'. As noted in the introduction, this was Irving Janis' claim about his own use of the term, and Whyte's original groupthink article refers to "double-talk" (1952a, 11).

In the book, Whyte expressed dismay at the 'organization man' and his willingness to submit to the group. Organisations gave employees a stable career and a comfortable suburban family life.“ A really new idea affronts current agreement - it wouldn't be a new idea if it didn't - and the group - impelled as it is to agreement, is instinctively hostile to that which is divisive. With wise leadership it can offset this bias, but the essential urge will still to be unity, to consensus $(1956,52)$." Whyte saw universities as complicit in this indoctrination process. They were breeding a generation of bureaucrats, and not just for corporations. "The lawyers, the doctors, the scientists - their occupations are also subject to the same centralization, the same trend to group work and to bureaucratization...theirs will be a generation of bureaucrats." (64). This was reflected in the rise of vocational training and a practical curriculum, with an associated decline in a liberal, intellectual education.

Whyte's critique contributed to an intense debate about the developing field of human relations. This was developed in Harvard Business School during the interwar period and is most famously associated with the research of Elton Mayo (O’Connor, 1999). By the start of 
the 1950s human relations had come to dominate the HBS curriculum, its central tenets sold by organisational psychologists. Particularly influential were applications of group dynamics, based on the work of Kurt Lewin. Whyte targeted human relations in The Organization Man, acknowledging that Mayo had made a valuable contribution by prioritising the human dimension at a time when the mechanistic worldview of scientific management dominated. However, he felt Mayo's pushing of 'belongingness' as the key missing ingredient in the workplace was coming at the expense of the individual. The rise of big business in the $20^{\text {th }}$ century created an increasingly wider gap in the employee/employer relationship, with corporations "physically and emotionally removed from local communities" (Khurana, 2007, 32). Whyte was concerned that literature touting the importance of group dynamics was reinforced by scientific evidence which claimed to have proven the group's superiority. If you analysed problems in organizations only through the lens of group dynamics, he said, you would also diagnose it as disharmony within the group, which could be missing the real cause.

\section{Whyte in context: Management studies in the 1950s}

By the mid-50's everyone was more cheerful. And why not? Corporations were expanding; more managerial jobs were opening up. Corporations were becoming more pleasant places to work in; more were applying the human-relations ideology of the Harvard Business School. There need be no conflict between the individual and the organization, and if there were, it could be resolved with a little social manipulation.

Whyte (1986, para. 4).

Whyte's critiques had a popular audience, with Whyte accompanied by numerous prominent 1950s writers questioning narratives about the security of working for large organisations. A closer analysis of the key discussions in these debates can open the possibility for new debates in a way that simply repeating Irving Janis' 1972 foreign policy ideas has not. This literature was characterised by a suspicion of "the content disseminated by the mass media favor[ing] the existing business system" (Blaisdell, 1957, 212). Inextricably connected to the 1950s rise of big business was the corresponding rise in degree programs. Academic studies in commerce were in high demand, with every year bringing more jobs and journals in which to publish (Starbuck, 2003). This led to the development of many human relations subfields, few of which focused on the (increasing) connections between organizations and social 
problems, "as business students dislike hearing that their future occupations have negative aspects" (Starbuck, 2003, 442). Popular 1950s management literature reacted to these changes with unease about the increasing size and power of big business and the corresponding dangers of "group-think, conformity, togetherness, adjustment, [and] otherdirectedness" (Tannenbaum et al., 1961, 17). These different terms described the same basic fears centering around a suspicion of the desire for harmony expressed within the contemporary business environment. Group dynamics were popular, but writers were unhappy that this allowed organisations to "adopt paternalistic policies" and "indoctrination programs" (Starbuck, 1965, 474).

As the emphasis placed on the value of group work grew within organizations, so did the number of writers concerned about the drift away from individualism. These critical texts included David Riesman's The Lonely Crowd, a sociological analysis of American culture (Riesman et al., 1950) and C. Wright Mills' (1951) White Collar studies of the American middle class. The Organization Man was published the same year as Mills' The Power Elite (1956a) and was followed by John Kenneth Galbraith's (1958) critique of the so-called 'affluent society'. The Organization Man also reflected social scientists' challenges to the structure and dynamics of bureaucracy (Blau, 1956; Gouldner, 1954; Merton, 1957). Peter Drucker also critiqued human relations in The Practice of Management (1954). While it initially "was one of the great liberating forces, knocking off blinkers that management had been wearing for a century" (278), it was now making "primarily a negative contribution" (278). Like Whyte, Drucker thought that the group focus was excessive and had failed to acknowledge questions of power which could not be wished away by largely empty slogans such as 'the happy worker is a productive worker'. Drucker believed human relations had developed "an almost panicky fear of the labor union" (279) and a "strongly manipulative tendency" (279) to diagnose any rational opposition to management as the result of maladaptive individuals.

An early textbook by Dalton (1959) noted these calls for individuals to assert themselves, and referred to several prominent academics criticizing groups: "These pleas - in various veins by H.F. Wilkie, W.H. Whyte, Jr., D. Riesman, and Orwell - are focusing too much on the visible" (272). Dalton claimed that these writers mistook surface conformity for total conformity, though making such a distinction could be said to miss the point, as surely these functionally have a similar result: submission. These themes were also observed by Baritz in The Servants of Power (1960), highlighting the managerialist and anti-union stance of Elton 
Mayo, for whom "industrial cooperation meant that labor should do as management said" (113). Baritz observed that as human relations grew increasingly popular it was almost impossible for managers to resist: "One either authorized human-relations research or was made to feel like an anachronism left over from the Neolithic period.” (173). The obsession with the group as the unit of analysis enabled management to hoodwink employees into believing that they had been involved in decision making. Baritz criticised industrial psychologists most strongly for ignoring their intellectual obligations to society, instead selling their knowledge and their soul to the corporation.

\section{Responses to Whyte beyond the 1950s}

The 1950s debate about conformity, and the centrality of William H. Whyte to this field, led to a lively discussion in management textbooks and academic papers as scholars debated the value of these contributions. In compiling data to create a counter-history focusing on Whyte, it is necessary to take a roughly chronological view of the continuing references to Whyte's work, to determine how representation of his ideas has changed. This means embarking on a journey to trace the evolution of Whyte's ideas, primarily as represented in textbooks, from the 1950s to the 2020s. The massive success of The Organization Man, in which Whyte did not use the term groupthink, meant that by the late 1950s references to groupthink started to thin. For example, Blaisdell (1957) refers to Whyte's ideas as describing a system called "groupism" (58). Eenigenburg (1961) also opts for "groupism" (5), though in a section based on Whyte's ideas references a "Group-Thinkometer" (5). The Modern Organization textbook by Victor A. Thompson (1961) references Whyte many times and refers to "group thinking" (88) amidst a discussion of consensus, though does not directly cite Whyte here. However, Whyte's work, particularly The Organization Man, was still regularly cited in the 1960s and 1970s. Looking back at the 1950s, Bahmer (1963) discussed the role of Whyte's work in popularising the notion that "large modern organizations and individual opportunity are incompatible" (7). Comparisons to Whyte's prominent academic contemporaries continued to be commonplace, particularly David Riesman's writing (Athos \& Coffey, 1968, 315; Thomas, 1957, 423; McGuire, 1964, 239). Bertram M. Gross (1964a) even compared Whyte's work to the bleak fiction of Huxley, Orwell, and Kafka, noting that the organization man and Social Ethic was "a softer, but still rather devastating" (78) picture of conformity. Gross (1964b) emphasised that while Whyte "counsels personal rebellion against expectations of total conformity" (816) he was not anti-organisation. Gross extrapolated from 
Whyte's writing that an "organizational individualism" (816) is what he may have been counselling, which can be achieved partially by belonging to many different groups. This could combine notions of togetherness with personal uniqueness: social needs are met but with no single group having a monopoly on someone's identity.

Miner $(1963,146)$ noted Whyte's ethical qualms but believed that much of the population would react with significant anger and resistance if they truly believed that the organisation was intruding into their lives excessively. The political aspect of Whyte's criticism was not neglected, with an article in the California Management Review (Cheit, 1964) discussing Whyte's criticism of the free enterprise campaign. Cheit also criticised the campaign for "masquerading as a nonpartisan effort" (4) while "its actual aims - reducing high marginal rates of income taxation and reversing a labor policy favorable to union organization - were frankly political." (4). Discussion of the anti-union activity of organisations is a recurring theme in these texts, and a good indication of a benevolent façade on the part of big business, preaching unity while limiting mechanisms for negotiation. Whyte's work also came to the attention of social scientist and key figure in the development of modern management Douglas McGregor, who cited Is Anybody Listening? and shared Whyte's scepticism about American management's costly attempts to communicate to workers (1958). McGregor claimed that there was a significant perception that groups were "inherently inefficient and time-wasting" (McGregor, 1962, as cited in Bennis et al., 1966, 249) and prone to conformity pressures. But he reached a gloomy conclusion: "Unfortunately, we cannot get along without groups" (1966, 249). Some writers went slightly further, with Koontz and O’Donnell (1968) granting that Whyte's thesis of excessive conformity was perhaps reasonable, but they claimed (in a section directed towards advising an aspiring future manager) that "The question is not conformity, but the degree; no one can operate as a member of a group without some conformity" (788). Rosemary Stewart (1967) in The Reality of Management praised Whyte and credited his book for unsettling top management, though noting that "there will always be a clash between the need for managers to be reliable and the dangers of over-conformity" (27).

Robert Golembiewski's (1965) textbook is full of references to Whyte, praising his "formidable sales record" (15) and the "craftsman's job" (16) with which The Organization Man brought moral criticism of organisations "vividly to public attention" (38). He criticises Whyte's attack on personality tests, however: "He does not concern himself with why psychological tests emphasize the conformist, the pedestrian, the unimaginative..." (89). 
Golembiewski contends that psychological evaluation in business does sometimes seek conformity, looking for the sort of employees least likely to 'rock the boat', but that this is not due to some inherent flaw in human relations. He deems that Whyte advising readers to cheat in these tests is "a pitiful challenge" (89) to the relevant questions of morality. Foell (1965) is indicative of the slow drift from groupthink as a Whyte conception. He references the value of Whyte's work with Fortune, and the fact that such criticism "is not observed in Fortune's sister magazine, Time, or in its competitors" (9), and even uses the term groupthink. But he attributes the word to Orwell. Longenecker (1969) included a particularly extensive section about The Organization Man in the second edition of his Principles of Management and Organizational Behavior textbook, believing that "the social ethic has permeated modern business" (422) and expressing concern. He again drew attention to Whyte's concept that selecting organisation men was an active task where "human relations skills become a prime quality of the candidate" (423), with top management generally happy to settle for dull subordinates over possible status quo disruptors.

While the term groupthink became absent in 1970s discussions of Whyte's work, the spirit of Whyte's vision of groupthink was not lost and can often be found in insightful interpretations of the organization man concept. The sense of a 'rationalised conformity' in which the group is actively demanding that members "give up their freedom for the overall good of the organization" (Hodgetts \& Altman, 1979, 267) is usually present in academic works referencing Whyte in this time. This is significant as it was the (post-Janis) 1970s where this sense of agency faded from discussions of 'groupthink' itself. As a Janis notion, the textbook portrayal tends more towards an unfortunate blunder made in some groups.

Karlins and Abelson (1970) highlighted Whyte's studies regarding the organisation's intrusion into family life. There was also a sense of class awareness, with Bass and Barrett $(1972,140)$ noting that Whyte believed that conformity was more rigid at the bottom of an organisation's hierarchy. Turner et al. (1972) expressed disapproval of the "evangelical zeal" (352) of some anti-conformity writers, though claimed that Whyte and Riesman in particular "defined the form of social criticism" (352) in the 1950s. They also noted that there was much future potential for research of this kind, with the ability to improve efficiency in organisations as well as happiness. Bensman and Vidich (1971) also compared Riesman's contribution with Whyte's, as well as the work of C. Wright Mills and an essay written by renowned German sociologist Max Weber regarding the Protestant ethic. In comparisons between these men, the authors found that Whyte more directly linked his findings to "large- 
scale bureaucratic enterprise" (48), and the notion of bureaucrats' personalities centring around bland agreeability and cooperation. Such traits were necessary for their survival. The conclusion was that "the corporation does not grant very much freedom" (172). Tough (1979), following a reference to Is Anybody Listening?, suggested that things may have been changing since Whyte's initial claims, and that the 1970s saw "some shift toward accepting the individual's needs and interests" (72). Writing in hindsight, Khurana (2007) also identified the 1970 s as a time where postwar trust in American corporations was eroding. Dowling and Pfeffer (1975) indicated a similar notion, discussing Whyte's mission in Is Anybody Listening? to review the 1950s campaign to sell free enterprise, while referring to modern business' "crisis of legitimacy" (128). Silk and Vogel $(1976,170)$ contended that Whyte's vision remained as relevant as when it was first written, claiming that little had changed regarding inadequate (yet overbearing) communication in business.

\section{Changing textbooks: From Whyte to Janis}

But this lively debate died down. By the 1980s, references to Whyte were increasingly uncommon, and groupthink was already being attributed to Janis in most cases. How did this happen? The treatment of groupthink by major textbook author Keith Davis over multiple editions illustrates the slow obscuring of Whyte's role in developing groupthink and critiquing human relations. The first two editions of Davis' Human Relations books, published in 1957 and 1962, refer to Whyte as the originator of the groupthink concept. Although Davis did not believe the situation was as dire as Whyte suggested, he did accept that "business is not immune to the groupthink trend" (1957, 284). Managers, Davis argued, in their enthusiasm to embrace developments in human relations, should be wary of the dangers of conformity and blind submission, which can lead to a situation where "by letting others decide, the groupthinker feels that he decides" (284), resulting in amoral decision making: the group decides. Referring multiple times to groupthink as a philosophy indicates support of Whyte's notion that groupthink is not purely accidental, but to some extent engineered.

Comparing the text of the first edition with the second edition (1962) shows that the content is almost unchanged - but with an instance where the word "businessmen" $(1957,284)$ is replaced with "managers" $(1962,419)$ in the latter. Likewise, "business" $(1957,284)$ becomes "management" $(1962,419)$, perhaps already indicating a shift towards textbooks using a primarily 'managerial' perspective. Davis also completely omits a section that 
concluded the first edition's groupthink analysis, warning that businessmen "should not conclude that the values of these [human relations] developments lie in group conformity or subservience" $(1957,284)$, and claiming that group meetings applied wrongly are without value. The other notable second edition change is that Whyte is still cited for groupthink but is now relegated to the footnotes rather than appearing within the body of the text.

A continued examination of Davis' representation of groupthink sees Whyte continue to rapidly be relegated to history. Davis (1963) wrote a chapter about togetherness in an edited work (Bowman \& Fillerup, 1963). Here, the citation for groupthink's origin has returned to the main text. However, the slide away from William H. Whyte continues. The chapter credits the wrong Whyte (the sociologist William Foote Whyte). Davis sets out a moderate position, suggesting the possibility of a middle ground "between the two extremes of overprotection by formal organizations and anonymous irresponsibility in some informal organizations" (51). Like Riesman's inner- and outer-directedness, and Whyte's Protestant and social ethic, Davis offers a duality of his own to describe these concepts - maternalism and paternalism. Davis' third edition of Human Relations at Work (1967 - the first to refer to 'organizational behavior' in its title), and the fourth edition (1972), published the same year as Victims of Groupthink, demonstrate a continued interest in Whyte and conformity, with a new section on The Organization Man which compares Whyte's ideas to those posited by Chris Argyris, both authors "simply want the organization to serve man, rather than the other way around.” $(1972,236)$. But while groupthink is discussed elsewhere in the book (in a very similar way to the first two editions), there is now no Whyte citation in either the text or the footnotes.

The Organization Man section remains mostly unchanged in the fifth (1977) edition, the first post-Victims of Groupthink edition. There is now no reference to groupthink anywhere. In the sixth edition (1981) there is a section claiming that a convincing criticism of meetings and committees is that conformity is a frequent result, and that "the tendency of a group to bring individual thinking in line with the average quality of the group's thinking is called the leveling effect or "group-think"(189). While there is no citation for the phrase, the influence of Whyte is still present, with the foregrounding of the negative effect on individualism. The usual hallmarks of Janis' foreign policy approach are not present. By 1985 and the seventh edition, Davis had a new co-author, John Newstrom, and the end of this section is amended with a comment about reducing groupthink with a devil's advocate to challenge ideas. This is a central Janis idea, and his first entry to the Davis books in any context. After Keith Davis 
died, his Human Relations series continued with Newstrom at the helm. The $12^{\text {th }}$ edition (2007) still contains remnants of Davis' claims about conformity, but the groupthink discussion cites Janis and contains bullet points of his eight symptoms. The contribution of Whyte to groupthink is lost.

Examining the textbooks by popular writer Harold Leavitt reveals a similar trajectory. The first edition of Leavitt's Readings on Managerial Psychology (1964) includes a reading by Cartwright and Lippitt including the term groupthink. While Whyte is not mentioned by name, the source is evident. Yet in the later $3^{\text {rd }}$ edition (1980), this reading is gone, while a reprint of Janis' 1971 groupthink article is included. Leavitt also wrote five editions of Managerial Psychology in the $20^{\text {th }}$ century. As already noted, the first edition (1958) featured "group-thinkers" without a direct citation, but indicates pre-Janis awareness of the term, and familiarity with Whyte is evidenced from references to his 1954 article on personality tests, and The Organization Man. The third edition (1972), published in the same year as Janis' Victims of Groupthink, features references to neither Whyte nor Janis. In the $4^{\text {th }}$ edition (1978), the citations twice reference Victims of Groupthink, though there is no direct use of the term within the text, despite a detailed analysis of group pressures and the potential value of individuals deviating from group norms. This remains virtually unchanged in the $5^{\text {th }}$ edition (1988), in which Whyte no longer features.

\section{Whyte, out: A change of career}

But where was William $\mathrm{H}$. Whyte himself as this shift was occurring? By the time of The Organization Man's publication his career interests were already shifting. He started writing about city planning while at Fortune and commissioned Jane Jacobs to write articles that were a precursor to her classic book The Death and Life of Great American Cities (1961). Disappointed not to have been chosen to be Fortune's managing editor, he left in 1959 to focus on urban planning issues, especially as they related to conservation (Birch, 1986; Nocera, 2002). While Janis' groupthink was catching alight, Whyte spent much of 1972 in New York sitting in plazas and watching pedestrians, pining for big trees and accessible water features (Whyte, 1972). Not that he was unhappy - it was in this career that he stayed for the rest of his life, and he spent the next 40 years improving America's landscape and cities.

In the realm of city planning, Whyte is far from forgotten. His legacy looms large. The 2006 book The Human Metropolis edited by Rutherford H. Platt is a good example of this legacy. 
The book is not strictly 'about' Whyte - it purports to be a collection of articles about making American urban spaces more habitable and equitable. But Whyte is ever-present (and often fondly referred to as "Holly", a contraction of his middle name Hollingsworth). Balsley $(2006,37)$ emphasised the significant posthumous influence of Whyte's principles and "commonsense observations" in helping "the silent constituency he observed and championed". Popper \& Popper (2006) directly drew parallels between The Organization Man and Whyte's city planning work, demonstrating that they are two sides of the same coin. His advocacy for open spaces was noted. Whyte observed that people in plazas preferred to be able to move their chairs, making the decision for their seating arrangements as individuals. This is one of many examples offered illustrating that despite Whyte's new career he remained interested in criticising organisations seeking predictability and consensus. Wiley-Schwartz (2006) cited New York's Bryant Park as Whyte's most enduring legacy. His transformative redesign of the formerly run-down and crime-ridden park included the free-seating arrangement discussed by Popper and Popper, as well as the removal of walls and fences. In the sense of working tirelessly to champion people, and fighting for the importance of the individual, Whyte's city planning work closely mirrored his time as a journalist.

There is minimal evidence to reveal whether he cared about the groupthink term becoming rapidly synonymous with Irving Janis, since William $\mathrm{H}$. Whyte did not keep personal diaries and rarely spoke about his earlier writing. But it seems that his views on human relations changed little. One of the few statements given by Whyte (1986) about his old ideas backed away slightly from branding people conformists with an acknowledgment of being an organisation man himself. But he insisted that the organisation man was still very much alive. The United States continued to be dominated by large companies, and there was still immense faith in the system. He acknowledged that employees in the 1980s were less inclined to be loyal to one organisation but were still fundamentally driven by allegiance to the system. While they were outwardly mobile, they were moving between interchangeable organisations. Choice was illusory. When interviewed in the following year by Polman (1987), Whyte noted that while people were more cynical they had not gained a new faith in their abilities to steer their own destinies. He acknowledged the criticisms of the lack of a "happy ending" for The Organization Man but did not believe that he could report one. 


\section{The critique of group dynamics fades away}

As Whyte's personal interests evolved in a direction away from his writing on groupthink, human relations also evolved in a way that obscured Whyte's hand. This shift away from significant critique of group dynamics can be illustrated by examining successive editions of Wren's The Evolution of Management Thought, the field's seminal history text. In the first edition (1972), Wren devotes an entire chapter to criticisms of Mayo's experiments at Hawthorne and the development of human relations as a field. Included is a section 'Conclusions regarding social man' that begins with McMurray's (1958) article in Harvard Business Review which argued that organisational innovation can be stifled by group pressures, because of members' desire to conform to the group and their reluctance to voice disagreement. Wren notes that "William $\mathrm{H}$. Whyte has also decried the exaltation of the group to the detriment of the individual" (378) and outlines his theory of the social ethic from The Organization Man. Wren then details McNair's (1957) “indictment of the human relations approach" (378), which was also published in Harvard Business Review. McNair complained that human relations treats people like children, suppresses individual responsibility and creates conformity to the group. Wren concludes this section by discussing the evangelism and mysticism that characterized human relations training.

Wren's second edition (1979) contains the same material as the first edition, but there is a significant shift in the third edition (1987). The title of the chapter changes from 'Social man and the critics' to 'Human relations in concept and practice'. The section 'Conclusions regarding social man' disappears. McNair's (1957) critique is retained as part of a new section 'The premises of an industrial civilization' but absent from this edition and all subsequent ones are McMurray's and Whyte's concerns about group conformity dangers. The debate that had energised management studies in the 1950s had subsided, obscuring Whyte's role in the creation of groupthink. Little has changed since. Despite the significant impact of Whyte's conceptualization of groupthink on the field of management studies in the 1950s, management textbooks make no mention of the alternative history of the origins of groupthink presented here. Whyte is mentioned in some textbooks, especially those authored by critical management scholars such as Clegg et al. (2019) and King and Lawley (2019), but no connection is drawn between his ideas in "Groupthink" and The Organization Man. Whyte's critique of the stifling of creativity in the 1950s is acknowledged in King and Lawley's textbook, but groupthink appears in a chapter on 'Managing groups and teams' and is a term coined by Irving Janis, we are told. 


\section{Death of an organisation man}

In the years following the increased popularity of Janis' groupthink and Whyte's movement away from organisation studies, a debate started to emerge about the relevance of The Organization Man, or lack thereof. Not only had Whyte's role in groupthink been marginalised, his best-known work on conformity was in danger. Feldman and Arnold (1983) discussed Whyte's initial claims but claimed that "twenty-five years later, we find a very different situation" (68). This claim was based on concepts like horizontal mobility (people not being bothered about climbing vertical hierarchies), and the expansion of the notion of what 'career' meant. Increasingly a career began to describe a path through multiple organisations. Feldman and Arnold also expressed a belief that the assumption that organisations unilaterally controlled the individual was fading. The dedication to the organization that William H. Whyte depicted was now seen as "compulsive behavior" (209). 'Workaholism' was viewed with suspicion. However, this sense of a lack of devotion to the organisation did not equal freedom from it. The textbook goes on to depict minorities feeling marginalised and underpaid, but needing to work, and both blue-collar and white-collar workers struggling with salary, but feeling "locked in" (210). It seemed that while the organisation man was no longer characterised by devotion to the company, the sense of being trapped remained. The organisation still won.

The year 1984 was not the dystopia that Orwell depicted, but if organisations and conformity still ran rampant, surely Whyte's critique was more relevant than ever? As it turned out, not really. Brooke (1984) wrote in his textbook that "a champion of the individual against the organization once wrote of the intolerable human situation in an over-centralized society" (101). Whyte is afforded significant status here, but his name is relegated to the footnotes, and the use of "once" gives the sense that this was a long time ago, implying minimised relevance. Whyte himself directly addressed the argument that "a new generation, disillusioned by the corporation, less willing to extend loyalty, more venturesome, is taking over" (Whyte, 1986, para. 2). But he disagreed. While people talked differently, he saw their fundamental faith in the system as unchanged - particularly “today's M.B.A.'s and young urban professionals" (para. 2). Despite the American corporation going from "debacle to debacle" (para. 5) and a world in which "beneficence has gone out the window" (para. 5), Whyte believed that the domination of large organisations remarkably continued, "run much as they were before" (para. 6). Ott (1989) made a similar point to Whyte in his textbook, 
acknowledging that the 1980s 'yuppies' were a very different sort of person to the organization men of the 1950s. However, Ott wondered "whether the late 1980s yuppie system of beliefs and values does in fact leave individuals highly susceptible to carefully designed and executed organizational enculturation processes" (196). Ott contended that despite surface differences, conformity was still a possible pitfall. But these warnings were not particularly heeded. At the turn of the century, Lewis (1997) claimed that "the remarkable thing about Whyte's description of American business life is how thoroughly wrong it sounds...The Organization Man, if he ever existed, is dead now" (para. 5). This claim centred around "brilliant screwballs" (para. 8) or "millionerds" (para. 8) achieving significant status, and while they worked for corporations they were allegedly "enemies of the conformity one usually finds in such places" (para. 8).

William H. Whyte, Jr. died in 1999 aged 81. While Whyte once self-acknowledged as an organisation man, Joseph Nocera's foreword to an Organization Man reprint argued that he never was, on the basis that organisation men blend in. "Whyte, by contrast, was blessed with an independence of mind that he never shed and never tried to" (2002, x). An obituary by Godfrey Hodgson (1999) discussed Is Anybody Listening? and the conviction expressed within its pages that American business could not properly communicate to individuals, though Hodgson expressed some uncertainty about the man's ultimate purpose in his organisational writing. He was unsure "whether [Whyte] was saving human beings from corporate culture, or showing corporate business how to save itself from its prevailing flaws". Regardless, he concluded that one of Whyte's points was crystal clear - the need for business to stop denying the inherent conflict between the individual and the organisation. But most obituaries referencing Whyte's organisational work would only talk about The Organization Man. Is Anybody Listening? made scarce appearances, and groupthink was absent.

Groves (1999) wrote about Whyte shortly after his death, and quoted management professors Warren M. Bennis and Jay W. Lorsch, both of whom agreed that the book was "chillingly accurate" (para. 7) at that point in time, with Bennis noting its continued relevance. However, while Groves acknowledged the value of Whyte's work, she ultimately decided that "it would be ludicrous now to talk of an "organization man,"” (para. 15), citing workforce diversity as well as increased mobility. Nocera (2002) agreed that the modern method of interacting with corporations was different but added that "within companies, individuality is now a virtue instead of a vice" (ix). But he noted that some people, upon seeing this change, may then view Whyte as outdated, someone who made a few wild predictions in the 1950s. Nocera 
pinpointed the sudden challenges faced by the massive companies General Motors and IBM in the 1970s and 1980s, failing to innovate due to being staffed by organisation men. Nocera contended that this is when Whyte's fears were fully realized. However, "they belatedly took Whyte's advice to heart" (xvi), replacing leaders with "non-organization men" (xvi). Nocera's argument is that the message got through, and any sense of his ideas being dated stemmed from the fact that by the $21^{\text {st }}$ century they are now commonplace. Even while defending Whyte's vision, there is a sense from this analysis that the battle had been won. But the flexibility of modern workers may be overstated. Justin Fox (2013) wrote a Harvard Business Review article entitled 'The Bedraggled Return of the Organization Man', noting data from the United States Labor Department showing an upward path since 2006 for male workers' median job tenure, coinciding with a sharp drop in employment. Fox concludes that "if he has a job, he's becoming likelier to stick with it. These are organization men out of fear, not of a belief in the beneficence of their employers".

Hanson and O'Donohue (2010) analysed Whyte's legacy, stressing the context of his 1950s work but following the general tenor of the developing organisation man discourse and deciding that "most middle managers in large business organizations today are not Organization Men in the Whytian sense (99)". But they argued for the continued value of Whyte's passion, specifically his polemical intent directed at the human relations philosophy. They noted that Whyte's terminology had "limited direct applicability" (103) in the $21^{\text {st }}$ century, but that his central criticism was still relevant. They suggest the term 'organizationality'. This highlights that even in 'boundaryless' careers, willingness to work and make compromises for large organisations is essential for survival. But perhaps a new term is not needed. None of the writers arguing that Whyte's ideas could still be relevant have pointed out the other popular phrase that he created. This is likely due to a lack of awareness due to the established marginalisation of the fact.

But what about groupthink, in the sense of Whyte's initial coinage? It is true that workers no longer submit to one organisation. It is also true that "men" is increasingly inadequate for describing these workers. But if these people are still fundamentally in thrall to groups, then “groupthinker" might fit the bill. This section has explored Whyte's career, including his posthumous influence, finding a distinct change in textbooks representing Whyte's groupthink, particularly illustrated by comparing editions of the work of Davis and Leavitt. It is clear that groupthink is no longer viewed as a Whyte concept, but it is also clear that a 
significant interest remains in Whyte's ideas. Perhaps the latter could be further strengthened by a revival of the former? 


\section{CHAPTER 5 - Strengths and Limitations of Janis' Groupthink}

As the above exploration of William $\mathrm{H}$. Whyte is a counter-history, it is not the history of groupthink that most management scholars and students would know. The gradual changing of the textbook representation of groupthink has been explored, but why did Janis' version prevail and why does it continue to dominate? This chapter will examine the strengths of Janis' approach, as perceived by most management textbooks, as well as the possible limitations. This involves examining the representation of this work after the 1972 publication of Victims of Groupthink. Chapter 4 gave an insight into the timeline of Janis' slow domination of textbooks, and this chapter will delve into the specific ways that such textbooks presented groupthink when crediting Janis, in an attempt to determine the appeal of Janis' presentation of the idea. Textbooks' tendencies towards simple frameworks and bullet points will form part of this argument, as will the applicability to a managerial view of groupthink as a fixable problem. I will then delve into the academic studies into Janis' groupthink to determine the extent to which the phenomenon has been empirically investigated, and why the lack of evidence for Janis' groupthink makes it a curious inclusion in a usually scientifically-minded field.

\section{Janis' groupthink provides a simple diagnostic framework for managers}

As has been discussed, many textbooks explore the subject from the perspective of the manager. They imagine students as future managers and therefore search for content that can be applied by managers to solve organisational problems and improve profitability and productivity. Janis was not writing for the management studies community and did not anticipate that groupthink would be picked up by them, but crafted his work in a way that appealed. The use of historical case studies provided textbooks with ready-made examples to illustrate the theory's value. His eight symptoms, although motivated by a desire to assist empirical testing of his hypotheses, are an easily applied diagnostic framework for managers. In a textbook that frames itself as setting the reader up to be a successful manager, coming across a list of eight symptoms gives the reader a sense that they are to look out for these symptoms. Thankfully for the worried reader, these are usually followed by simple prescriptions for overcoming groupthink. This is perfect for management textbooks as it provides a common problem faced by managers and then an immediate solution, presented and explained simply as a list. Compiling textbooks is a lot of work and it lightens the burden 
somewhat to come across a managers' problem that is already neatly packaged and provides its own solution. Little more needs to be done.

\section{Janis' groupthink appeals to textbooks written to train managers}

"What can managers do to minimize groupthink?" asked Robbins and Judge (2009, 365). It is a question in which textbooks are very interested. Their mission is usually to teach students how to manage. Therefore it is logical that a discussion of groupthink would include how managers could deal with it. Greenberg and Baron (1995) directly state that their discussion of how managers can avoid groupthink is included "so as not to conclude on an entirely pessimistic note" (397). Usually these techniques are directly adapted from Janis' 1972 avoidance advice, framed as techniques that managers should enact. Wexley and Yukl (1984, 149) recommend that the leader should select the most appropriate groupthink-avoidance procedures in order to maintain a group's critical judgement, while Morley and Hoskin $(1984,85)$ highlight the leader's responsibility to "organize disagreement". Johns $(1996,397)$ rhetorically asks what can prevent groupthink and presents an answer: leaders. They can do this by establishing clear norms and dissent, but there is no notion that non-leaders can do so. Drummond $(2000,188)$ suggests the management of groupthink through leaders forcing group members to consider all possible consequences. Pheysey (1993) gives advice to managers about punishing mind-guards for concealing information.

John R. Schermerhorn Jr.'s Management for Productivity (1989) refers to groupthink as a "subtle" (397) issue in group cohesion, framing groupthink as one of the issues that managers have to face when influencing group norms and cohesiveness and in a later textbook Schermerhorn (1996) presents ideas regarding dealing with groupthink as a box-out, titled “The Effective Manager 12.2”. In Schermerhorn et al. (1995), the "Effective Manager" box prior to groupthink discusses "ten steps to group consensus" (139). While this does not necessarily contradict Janis' groupthink, the overriding message is that groups and teams are vital for decision-making, and that it is the role of the manager to correct their course - titles like Management for Productivity and "The Effective Manager" emphasise this notion.

Why is this sort of interpretation so widespread? Fineman and Gabriel (1994) can help to provide insight into the popularity of the textbook representation of ideas. Their broad study of textbooks noted the prominence in the 1980s and 1990s of case studies to demonstrate relevant concepts, usually from a managerial standpoint. According to Fineman and Gabriel (382-383), a good case study is one with a memorable and strong narrative, but they point out 
that this is often lacking due to the need to condense these narratives to fit into textbooks. The representation of Janis is a good example of this. Janis' narratives are at least compelling, with well-drawn characterization and memorable plots. But textbooks generally only allocate space to list the symptoms and very briefly reference some of the foreign policy disasters pointed out by Janis and subsequent writers. This is inevitably less effective than the original work. Information must be condensed to some extent as it is unreasonable to expect students to have a working knowledge of the complexities of each theory. But if the information is not engaging, it will not be absorbed. Moorhead and Griffin (1992) provide a notably comprehensive study of groupthink in their textbook, but also provide an example of a perfunctory case study reference, noting that "groupthink can occur in decision making within organizations, as may have been the case in the E.F. Hutton checking scandal" (504). A footnote to a relevant academic article is included, but in terms of the material provided in the textbook itself, this is unlikely to illustrate to students a relevant example of groupthink. If they do not know what the E.F. Hutton checking scandal is, it is hard for this to be of immediate use.

Fineman and Gabriel (1994) also discuss the prevalence of lists in textbooks, arguing that they present information in a way that will help students to memorise for a test, but are actually substituting arguments rather than summarizing them - the information is communicated efficiently but sparsely. The effect of this presentation is that authors' names appear on lists as just another item. Considering this point regarding the representation of Janis, the claim has merit. Most students' understanding of Irving Janis will be as the author of two lists about groupthink. But as this is essentially all that they are told about him and his ideas, he is functionally just a part of the list.

\section{Janis' groupthink reinforces the value of group dynamics}

But the continued representation of Irving Janis' initial groupthink argument (as well as subsequent writers closely following his model) may also be supporting a specific ideology, and deliberately 'playing it safe'. Janis' work on groupthink warns against conformity and encourages valuing the individual. Some textbooks highlight this, noting that the "collective norm can stifle the loner, the maverick, and the independent person" (Lawless, 1979, 326) or the "destructive effect" on individuals (Schwartzman, 1989, 210). Morley and Hoskin (1984) emphasised that group decision making is important but not necessarily superior, and in a discussion of Janis' groupthink they highlight that groupthink is a process in which 
"conformity is induced through direct pressure" (84) to eliminate dissent. Other books downplay this, prefacing the discussion with a caveat that group cohesiveness is "generally a positive thing" (Huczynski \& Buchanan, 2001, 755). Groupthink often features in a small section regarding possible group limitations - a minor island of potential negativity in a sea of praise for the effectiveness of group work. Certo (1994) briefly mentions groupthink amidst a substantial section about "What Makes Committees Successful" (407), recommending how a manager can devise committees as an effective tool. Yet even within these brief discussions, there can be a reticence to blame groups as problematic, with claims that groupthink is not inherent in every group decision (Bedeian, 1986, 498). Pheysey (1993) even notes that "decisions made by group think do not all turn out to be bad decisions" (127). It is often noted that groupthink largely occurs in "extreme cases" (Elkin \& Inkson, 2000, 194). This includes when a group faces an external crisis (Greenberg \& Baron, 1993). Some books (Kalliath et al., 2010) nestle discussion of groupthink amongst several theories about 'team potency' and other largely positive representations of group behavior. There is little space for discussion of individualism's value. Flaws in group work are framed as something to minimise while maximizing the assets, using the group as a productivity resource (Wood et al., 2006). Following a brief explanation of groupthink, Stoner (1982) reassures readers that "there is another side to the story" (344) - efficiency (at the expense of individualism). "Time can be saved when a manager communicates with a number of subordinates at a meeting, instead of on a one-to-one basis. In addition, problems may be solved faster and more effectively with all of the relevant people in the same room at the same time" (344). These examples give a sense that Janis' groupthink, although critical of conformity, can be easily adapted to a managerial standpoint.

\section{Janis' groupthink relates to well-known cases}

Textbooks closely follow Janis' precedent of presenting well-known cases to illustrate the concept. Students in the 1970s and 1980s were familiar with the recent Bay of Pigs and Vietnam war debacles (textbooks discussing these examples include: Lawless, 1979; Byrt, 1980; Stoner \& Wankel, 1986) but the 1990s saw a significant addition to common groupthink examples. Glen Whyte (no relation to William) analysed the 1986 space shuttle Challenger disaster using the lens of Janis' groupthink. His 1989 paper “Groupthink Reconsidered", published in Academy of Management Review, argued that intense pressures on the National Aeronautics and Space Administration (NASA) to launch the space shuttle 
resulted in NASA engineers not properly consulting available evidence that the shuttle's safety would be compromised by cold temperatures. Glen Whyte claimed that the explanation offered was not solely confined to military and governmental decisions but was "equally applicable to business decision making" (Whyte, 1989, 53). Like Janis, he was not specific about how such an application might be achieved. But the idea was popular and influential in textbook representations - the Challenger example was picked up rapidly. (Some textbooks to incorporate this include: Bartol \& Martin, 1991; Greenberg \& Baron, 1995; Vasu et al., 1998; Robbins \& Judge, 2009; Knights \& Willmott, 2017). A more recent illustration of a high-profile groupthink blunder was found in George W. Bush's administration's invasion of Iraq (King \& Lawley, 2019). It is asserted that the Iraq War was "pathologically driven by groupthink, which caused a shift in the administration's view of Saddam [Hussein] from a troubling dictator to an existential threat to US security" (Badie, 2010, 277). The Iraq and Challenger examples are the most common post-Janis adaptations of the groupthink, which shows minimal deviation from the format as these are both taken from major world news stories documenting hugely high-profile blunders. And despite various new applications of the theory, the Bay of Pigs example remains the most used, still cropping up in $21^{\text {st }}$ century textbooks (e.g. Elkin \& Inkson, 2000; Knights \& Willmott, 2017).

\section{Janis' limitations: Minimal progression from initial foreign policy case studies}

The repetition of Janis' foreign policy examples to illustrate groupthink is interesting. The preface to Victims of Groupthink shows that Janis did not imagine the business school as a key audience for his work: "This book is at the intersection of three disciplines - social psychology, political science, and history. I hope that the interpretations and theoretical conceptions suggested in the case studies will add something to the thinking of scholars in each of these disciplines" (1982, vi). Byrt (1980) claimed that there is "much evidence of groupthink occurring in meetings" (68) but did not elaborate on this aspect specifically. Luthans (1989) took a similar stance, acknowledging the value of Janis' notorious historical examples but pointing out that "it can commonly occur in committees in business firms or hospitals or any other type of organization." (383). The following justification for this claim is again limited, pointing to research providing partial support for a broader application but not providing specific examples for such organisations. Elsewhere it is claimed that "symptoms of groupthink are as likely to be seen in a corporate board meeting as in a 
classroom" (Robbins \& Mukerji, 1990, 80), but the discussion remains broad. It could apply to any context, but not enough background is given for the contexts referenced.

There is, however, some diversity in the claims made about groupthink in textbooks. Byrt (1980) discusses groupthink within political parties. Gordon (1993) claims that it is less likely to occur in multicultural groups. When textbooks diverge from the standard eight symptoms plus historical foreign policy approach, they sometimes mention the influence of George Orwell, or wrongly attribute the phrase itself to Orwell's novel 1984 (e.g. Stoner, 1982). Janis was transparent about an Orwellian influence - the connotation was deliberate. This means invoking the spirit of one of the best-known dystopian novels of the $20^{\text {th }}$ century, in which such terminology is utilised by the rulers of a totalitarian regime. It is curious, then, that Janis does not significantly expand upon this connection. He never attacks the system within which groupthink occurs.

Of course, this is not to say that Janis and subsequent textbook writers completely let organisations off the hook. Some writers illustrate a more direct relevance to business. Greenberg and Baron (1995) briefly (and without much specificity) mention crises faced by large corporations such as Chrysler and Lockheed. Dunford (1992) uses a case study involving computer corporation Compaq considering a merger to illustrate a practical example of Janis' devils' advocate idea. Keyton (2005) applies groupthink to the heavypressure culture at Enron before its collapse, and King and Lawley (2019) discuss the Volkswagen emissions scandal, where devices were created to enable the company's diesel cars to cheat emissions tests. These examples are interesting because they are generally not replicated in other textbooks. The sense is that management textbooks are mostly unwilling or unable to apply groupthink to business. The foreign policy examples have a track record and have been widely written about. They are safe. Of course, this does not necessarily translate to them being the best examples for effective teaching - there is little sense that such well-trodden examples will continue to stimulate students.

\section{Janis' limitations: Minimal evidence}

Management textbooks commonly seek to secure legitimacy by highlighting their scientific credentials. But when covering groupthink, scientific evidence is largely absent. Textbooks seem to be happy to overlook this absence of empirical validation for Janis' theory. This is reminiscent of the critical study into Maslow's hierarchy of needs by Dye et al. (2005), where it was found that despite the hierarchy's massive popularity in business, testing has been 
largely disappointing. Janis' well-known cases present stories with which most of his audience will be familiar, and therefore there may be less willingness to question his conclusions, including the lack of scientific evidence supporting Janis' groupthink phenomenon. Janis did not attempt to deny this: "The evidence needed to test hypotheses about the causes of groupthink must ultimately come from field experiments and other systematic investigations specifically designed to pin down causal sequences, rather than from historical case studies, which are useful mainly for suggesting hypotheses" $(1972,202)$. Part of the rationale for creating the eight-symptom framework was to present something that could be tested by future researchers: "we must operationalize the concept of groupthink by describing the symptoms to which it refers." $(1972,197)$. Janis did not frame Victims of Groupthink as a definitive, rigorous statement. It is perhaps better described as a provocation - a starting point for more overtly scientific research.

Nearly fifty years later, this scientific evidence has not arrived. There is not a single credible, influential study showing a positive relationship with all of Janis' symptoms, despite numerous attempts. Flowers (1977) and Courtright (1978) researched groupthink in a laboratory setting, with some secondary support but no strong primary support to validate the notion. Callaway and Esser (1984) also achieved only "mixed support" (163). Leana (1985) investigated groupthink in a laboratory setting, finding only "partial support" (15) for Janis' model. One of the specific findings was that group cohesiveness did not have a detrimental effect. In fact, cohesive groups were less likely to engage in self-censoring, limiting behaviours. She noted that "before groupthink can be accepted as a potential pitfall in group decision making, controlled attempts to verify the model are not only desirable but highly necessary" (17). Some textbooks note Leana's findings regarding conformity, but while continuing to largely present groupthink as a valid potential pitfall.

Gregory Moorhead (1982) believed that proper examination of Janis' thesis was long overdue, and attempted to rectify this. Moorhead and Montanari (1986) noted that this lack of research may have been due to "the failure of Janis to develop a concise theoretical framework" (400). They then attempted to rectify the perceived issues with the few tests that had been done, using previously established groups rather than forming them ad hoc for the experiment, and testing for all of Janis' symptoms and defects, not just some. This also proved disappointing however, with no direct effects on group performance. Overall, studies have provided mixed support at best. This can be further evidenced in literature reviews including: Park, 1990; Turner et al., 1992; Aldag \& Fuller, 1993. There is some 
dissatisfaction with groupthink in the foreign policy realm as well. The editors of the book Beyond Groupthink ('t Hart et al., 1997) emphasised a respect for Janis' work and legacy, but expressed a desire to assess " 25 years of groupthink-dominated small group research"(29) and to break free from the constraints of groupthink and develop new strategies for group research.

Victor Wekselberg (1996) analysed research into groupthink since Janis' 1971 article, as well as examining a sample of textbooks representing groupthink. He criticised these books for their largely uncritical representation of the theory. He argued that the concept "provided a tool to obscure social problems rather than solve them" (226) and focused on the "long history of failure" (226) in its research. It is concerning, stated Wekselberg, that textbooks continue to feature groupthink without a clear consensus about what it is or evidence that it even exists. Some do register a sense of unease about groupthink's validity (Johns, 1996; Kreitner \& Kinicki, 2008). At the end of an unusually expansive look at groupthink, Moorhead and Griffin (1992) concluded that despite convincing arguments for the concept, "the hypothesis has not been subjected to rigorous empirical examination. Research supports parts of the model but leaves some questions unanswered" (506). Bowditch et al. (2008) refer to post-Janis research raising questions about the applicability of groupthink in the workplace, and note the studies failing to prove it (though they also criticised the studies one can see why Wekselberg was concerned about textbooks confusing students). Others refer to groupthink models as "incomplete" (Roberts \& Hunt, 1991, 346), or provide a less specific acknowledgement of "some controversy" (Knights \& Willmott, 2017, 394). Brooks (1999) notes that Janis' case study approach "struck a very practical note of reality" (94), and described his work as developing Solomon Asch's 1951 conformity studies, while cautioning that Janis' foreign policy focus is not necessarily applicable to the context of "today's business organisations" (95). Despite these significant criticisms, most of the above authors still repeat Janis' eight symptoms framework and how it applies to his and other famous cases.

\section{Conclusion: Groupthink beyond Janis}

Upon his death in 1990, Irving Janis' apparent coinage of the groupthink concept (as a "sometimes risky" element of "high-powered political and corporate circles" (New York Times, 1990, 44)) was his best-known achievement. A concept that he did not create. It is unlikely that this bothered Janis significantly, as much of his post-1972 work followed up on 
the concepts discussed in Victims of Groupthink. The man was an excellent scientist (Tetlock, 1991), and his psychological studies made a significant impact. Victims of Groupthink makes a thoughtful and interesting case. Raising awareness of the dangers of conformity is a noble quest, at which Janis succeeded. But there is value in another perspective. One which does not reject Janis' contribution, but discusses the possible value of embracing the counterhistory where groupthink is a term suggested by William H. Whyte. Greater awareness of Whyte's groupthink can provide students and academics with a useful contrast with Janis', and if textbooks were to explicitly make these contrasts, a more multi-faceted notion of groupthink could arise. Janis' analysis of “sometimes risky” group decisions, mainly focusing on foreign policy groups, can still provide the value of a clear framework, and an argument that can increase understanding of the dangers of conformity from a managerial perspective. Whyte can provide an interpretation that both complements this and criticises it, allowing more focus on deep-rooted conformity issues that are deliberately implemented in organisations. This could allow textbooks to expand their coverage of groupthink, leading to a richer and more varied interpretation of these authors' vital arguments about the dangers of consensus. 


\section{CHAPTER 6 - Discussion}

This section will bring the threads of the previous chapters together, making a case for a richer view of groupthink and conformity. Janis and Whyte's versions of groupthink, and the representation of their work, will be directly compared so that a conclusion can be reached. I will ask for wider recognition of Whyte's groupthink work, constructing an argument about why his work deserves to be remembered and ultimately why his form of groupthink could be a better fit in modern society. With deconstructionist historical methodology in mind, this argument will be careful to avoid a call for Janis' work to be discredited or ignored, instead calling for Whyte and Janis to be recognised for parallel theories of groupthink. But a specific case for Whyte's relevance will be made, contributing to critical literature's attempts to directly engage with the historical contexts behind ideas. Embracing Whyte's groupthink will also mean illuminating the vigorous 1950s debates about the dangers of conformity in specific relation to human relations. Janis' work is valuable and interesting, but he was not part of this discussion, while Whyte was. Whyte's formulation of groupthink has clear relevance now, as he pulls no punches, framing groupthink as a specific ideology rife in seemingly benevolent and inclusive large organisations.

\section{Recognising Whyte}

Probably the least controversial recommendation that this paper will make is to reinstate Whyte's place in the historical record as the creator of the groupthink concept. It is important to point out that I do not seek to "reveal" erroneous facts about history and re-establish the truth regarding groupthink. Such an approach veers too close to the view that history is an accurate representation of exactly what happened in the past (Mills et al., 2014). The argument that has been presented regarding the forgetting of Whyte and the possible importance of remembering him, is a narrative approach. But it is a historic fact that William H. Whyte wrote about groupthink in 1952. It is a historic fact that Irving Janis wrote about groupthink in 1971. Whyte was first. But recommending a new awareness of Whyte's role in the term's genesis is not the only reason for this exploration into groupthink. A reconsideration of Whyte's theories could provide insight for present and future understandings of management. The story of Whyte's removal from representations of groupthink's origins can also add to ongoing attempts to explore marginalised corners of 
management history, to find important historical insights that have been forgotten or obscured.

\section{This woman's work: The rigour behind Whyte}

Chapter 5 featured an exploration of the lack of scientific testing for Janis' groupthink. Scientific testing is of course not the be-all and end-all of a theory's value, but I will not try to argue that William H. Whyte's notion of groupthink is scientifically testable than Janis'. The parameters for such a test would be difficult to define because he does not offer a framework as specific as Janis' eight symptoms, which translate well into experimental variables. But since the vast majority of texts credit Janis for groupthink, there has never been a concerted effort to test and build upon Whyte's ideas. They deserve at least some of the attention that has been lavished upon Janis' version. Still, it important to note that there was certainly academic rigour in Whyte's work. The preface to Is Anybody Listening? acknowledges the work of researcher Selma Wolff, claiming the book to be "very much hers as well as mine" (1952b, xii). Given that part of this thesis' aim is to illuminate the role of Whyte as a figure largely forgotten by management history, it would be wrong to ignore Wolff's role. However, a search for historical data about Selma Wolff reveals little. The Selma Wolff who died in 2019 aged 90 in Atlanta, Georgia could certainly have been Whyte's peer (Atlanta Jewish Times, 2019). If so, one can learn that she was a "devoted wife, mother, grandmother and great grandmother", but details of her career remain obscure. But her work was vital to Whyte's conclusions, and it is important to highlight this. Her research included surveying university students, management consultants and executives' wives, and though Whyte still denies a scientific approach, proudly describing "a book for laymen by a layman" (1952b, vii), this research took two years, and is a substantial legacy.

\section{Conformity: Comparing Whyte and Janis' arguments}

As has been explored, notions regarding the relevance of Whyte's ideas vary, with claims that following the 2008/09 recession, people have been forced to be organization men out of desperation (Fox, 2013). Hanson \& O'Donohue (2010) concede the "limited direct applicability" (103) of the organization man concept given the demise of an individual staying within a sole organization for a lifetime, but argue that Whyte's identification of the issue of group-focus limiting the individual is vital. Looking instead to Whyte's groupthink could be the answer. Whyte's ideas on conformity are undoubtedly still relevant today, 
particularly considering his demands for accountability from those in power. Whyte's view of groupthink presents a pervasive and pernicious social issue to be interrogated and held to account. This is also somewhat true of Janis' view, but he offers a clear overview and a set of answers, implying that capable managers can avoid pitfalls and maintain harmony among their workforce. This is not a bad thing. If every theory offered in management textbooks only gave a sense of existing societal issues and presented no clear sense of how they can be combated, they would be somewhat useless, and certainly a depressing read. A textbook that is entirely critical of management would be fairly bizarre given that it is fair to assume the majority of its readers have some interest in and fondness for the subject. But there must be room for criticism. The relevance and purpose of management ideas should be questioned to allow a greater variety of voices and subsequently a more complex and richer idea of the subject's key issues.

Whyte's groupthink can act as an effective mechanism for questioning Janis' generally accepted one. John B. Miner (2006) noted the publication of Whyte's work as central in sparking the interest in conformity in the 1950s and 1960s. Miner was an active writer in this period, so writes of personal recollections about following this conformity debate with fascination while it was occurring. He believed that the well started to run dry in the 1970s, and that nobody since had picked up on the promising beginnings in conformity theory. This is indicative either of a lack of awareness of Janis, or (more likely given the idea's prominence) deeming it not to be from the ideological lineage of the 1950s/1960s theorists and the academic debates that he witnessed. But while regretting his own drift away from writing about these issues, he adds that the potential for such research is significant for "an expanded understanding of institutionalization processes" (Miner, 2006, 236) - it is not too late to re-engage with these ideas. Delving into the work of William H. Whyte and Irving Janis, as this thesis has done, helps to approach a reasonable conclusion about why the former is not credited as groupthink's creator. It is unlikely that a fledgling academic field would want to recognise as a key contributor somebody whose writing threatened the very existence of the corporations where the management field was training its students to work (Starbuck, 2003; Beder, 2006).

\section{Whyte now: Does he have a place in the $21^{\text {st }}$ century?}

My answer to the above question is hopefully clear by now, but it is important to be specific, as this is a question that has been asked by others. Many examples of this were discussed in 
Chapter 4, and answers vary. Whyte himself directly contested the notion discussed in the 1980s that increasing mobility meant freedom from being organisation men, arguing that this was a new way to create the illusion of freedom. What about now? The claim of increased mobility is still one that is regularly made. It is very uncommon that a worker will stay with one organisation for decades. But the crucial point is that they will stay with the organisation. The notion of the gig economy is becoming increasingly popular. This describes the increase of freelance or temporary jobs and could be perceived as a role celebrating individual freedom. It allegedly allows more flexibility for lifestyles, and more adaptivity to the market. But gig workers lack job security. Their position is precarious by definition, and there is less ability as an independent contractor to stand up for oneself or oppose management. It seems likely that Whyte would make the same argument now as he did in the 1980s: this is another illusion of freedom, constructed by organisations. And people are still actively buying in, embracing this more precarious status quo, and encouraging others to do so. Could Janis' version of groupthink be adapted to reflect these concerns? Possibly, but as my study of representations of Janis' work has demonstrated, very few have achieved much success in substantially adapting and developing his original work. Whyte's work from 1952 and 1956 cannot be seamlessly transplanted to the modern day, but there is strong potential relevance. As the data analysed in this thesis has illustrated, Janis' groupthink may still be stranded in 1972, with a couple of small lifeboats just reaching the shores of the 1980s (Challenger) and the 2000s (The Iraq war).

Amidst a mostly standard discussion of groupthink as a Janis creation, Chell (1993, 93) noted that "Janis was concentrating his attention upon top policy-making groups, but what about lower-level decision-making groups in organizations?" It is a good question, and Whyte again may be able to provide insight here. In William H. Whyte's original 1952 groupthink article, he noted that "we are not talking about mere instinctive conformity - it is, after all, a perennial failing of mankind. What we are talking about is a rationalized conformity - an open, articulate philosophy which holds that group values are not only expedient but right and good as well." It could be argued that Janis' conception of groupthink helps to validate such a philosophy - "instinctive conformity" is essentially how the dangers of groupthink are framed in Janis' work (and textbooks representing him, for example: Dunford, 1992, 113). It is not group values themselves that are in question, but the misuse of them. Is this really criticism enough in a world where multinational corporations continue to expand, offering the hand of friendship in the form of groups and co-operation while continuing to undermine 
individuals' security and power to resist? The use of Janis' tools for dealing with groupthink tends to see improvement of the function of groups as an appropriate end goal. This is in essence the same thing that the social scientists whom Whyte criticised were trying to do and does not fix more fundamental issues with group ideologies being pushed.

Redding and Tompkins (1988) noted that "one could establish a [critical] genealogy reaching back to Whyte's Is Anybody Listening?" (22) They emphasised that Whyte's work criticised managerial assumptions, questioning the effectiveness of "a linear and mechanical model of communication in which it is assumed that pressing the right buttons will set workers in the proper motions" (26). So viewing these old concepts with fresh eyes could provide strong insights for a more critical look at management, even though it may initially feel counterintuitive as a method of creating a more thoughtful and diverse future for management studies (Miner, 2006). Since the calls for a newer adaptation of Janis' groupthink (see Mohamed and Wiebe, 1996) have not been satisfactorily achieved, it seems that there is little to lose in entertaining the possibility that Whyte's original version of groupthink may be more relevant and fruitful to organizational studies. Modern critical writers question whose interests are served by popular interpretations of management. Whyte asked the same question of group dynamics and concluded that it certainly was not the workers.

\section{Where does this leave Irving Janis?}

While this thesis attempts to make a case for the strength and relevance of Whyte's work, Irving Janis evidently had a deep interest in reducing conformity and improving lives. Russett $(1991,180)$ discussed his humanity and diligence, and his family's request that memorial contributions should go to "any effort that promotes world peace". Additionally, while the possible flaws in Janis' case study historical approach have been pointed out, this is done with great awareness that my study follows similar principles itself, with much justification of why a historical study is effective. The history that Janis creates to represent the past is interesting and provocative - its value is clear. But, continuing the comparison between this paper and Janis' work, my study offers an alternative to the present-focused status quo of organisational studies. It exists alongside these works. Because Janis' form of groupthink monopolises discussion of the concept, his narrative is all that is currently available. It is a potentially valid theory, but an alternative is available.

The textbook The Cultures of Work Organizations (Trice \& Beyer, 1993) is to some extent a precursor to the points made by this thesis, in microcosm. The book does not directly 
compare Janis and Whyte or mention the latter's role in groupthink. But a section on culture notes that "while the phenomenon of groupthink resembles culture in some respects, it is usually used in reference to relatively small, face-to-face groups...nor do the descriptions of groupthink portray the kinds of ongoingness and inclusiveness that characterize cultures" (20). As a description of Janis' groupthink, this is fairly apt. But Whyte's conception of groupthink is notably wider. He certainly stressed the dominance of inclusiveness, as well as the extensive scale of his groupthink notion: he is certainly discussing a culture. While stressing the small scale and shaky relevance to wider cultural concerns of Janis' groupthink, the book references Whyte's organization man several times, agreeing that while individuals still held notions of individualism strongly, the work organisation was deliberately constraining this. They noted his warning that "managers' conformity to the corporate norms would squash innovation and the creative capacity of individuals and organizations" (171). The book's different approaches to discussing Janis and Whyte regarding the question of extensive and deliberate conformity is indicative of the value of re-assessing Whyte's relevance. Janis' groupthink concept does not fit the authors' conformity argument, but perhaps a resurrection of Whyte's groupthink would.

\section{Contributions: A new example for critical studies}

Hugh Willmott's 1993 paper 'Strength is ignorance; Slavery is freedom' was a significant addition to the critical discussion of management studies. It discussed the concept of doublethink, taking Orwellian inspiration like Whyte and Janis. In Orwell's 1984, doublethink refers to the ability to hold two contradictory beliefs at the same time, believing both to be true. Willmott contended that this occurs in organisations, where employees are asked to identify with corporate culture and foster a belief in its 'values'. As a reward for doing this, greater autonomy is promised, but Willmott saw this as an extension of control of employees' thoughts and emotions. An individual will of course retain their own personal views and try to carry these out at the same time as the often-contradictory beliefs needed to be a good fit for the company (indeed, an 'organisation man'?).

The resurrection of Whyte's groupthink argument attempted here can offer a valuable contribution to critical management literature, providing a new example of a marginalised management concept. It is also valuable because Whyte's original work shares a common intent with critical studies. Deetz (1992) argued that the modern corporation's dominance in society "has eclipsed the state, family, residential community, and moral community" (2), 
and that corporations pervade life, even providing people with their personal identity. While I have mostly tried to avoid presenting a definitive, inarguable history of why the groupthink credit shifted from Whyte to Janis, some generalisations have been made about the past. But illustrating some sense of historical context is an important thing to attempt. William $\mathrm{H}$. Whyte specifically noted the relevance of the Great Depression to his work. The job instability created by the stock market crash was a key part of the context shaping Is Anybody Listening? and The Organization Man. Foster et al. (2014) note the absence of the 1930s in management literature, with minimal coverage of the decade's massive changes occurring in response to the Depression, including Franklin Roosevelt's New Deal. These times "were either ignored or scorned in management textbooks" (188), with management scholars perceiving that these issues were separate from management. Highlighting the Depression's influence on the historical debates referenced in this thesis is important for helping to redress the balance. It is also important to emphasise that Whyte's writing took place in an era that was heavily influenced by the ongoing Cold War context, where the notion that American democracy was "inextricably linked to support for corporations and management" (Khurana, 2007, 239). While Whyte was not unique in his criticism, he was writing in an era where "anything that looked like criticism of business aroused suspicion" (Khurana, 2007, 234). My argument is that Whyte's critique of 'the campaign for free enterprise' (Beder, 2006; Gable, 1953) offers a more critical lens for management scholars, and potentially a more powerful one. I hope that this is a significant contribution, illustrating the value of a historic study's ability to contextualise management concepts.

\section{Contributions: Textbook analysis}

This call for a renewed recognition of these ideas is a start. The next step is focusing on exactly how these ideas can be communicated. There are of course many avenues, but this analysis has primarily focused on the vital role of textbooks in disseminating management knowledge. The notion that problems of conformity tend to be minimised by best-selling textbooks is supported by research on the representation of Stanley Milgram's obedience to authority experiments (Bridgman \& Cummings, 2017). Milgram's experiments gave ordinary people the power to administer increasingly large electric shocks, which were eventually fatal. These shocks were faked: the people being 'shocked' were actors. But the people involved in the experiment did not know this. The results demonstrated the large extent to which people are prepared to compromise personal morality when instructed by an authority 
figure. These experiments are conspicuously absent from most organisational behaviour textbooks, despite them being seen by psychology textbooks as an exemplary experimental science and of great relevance to understanding human dynamics at work. Perhaps this is because their conclusions are too negative - the conclusion from these experiments is comparable to the warnings of Whyte's groupthink regarding individual values being compromised. In Milgram's experiment, this is due to a direct authority figure, whereas with groupthink the individual submits to the collective authority exerted by the group. This thesis also contributes to the notion of textbook analysis as a viable method of critical study of management. This has been articulated by theorists like Stambaugh and Trank (2010), and contributing to this field is important, as it can indicate to management researchers a different way of doing research. I have utilized 'old' data, with textbooks as the main source, to construct a new argument with recommendations for the future of management learning. Hopefully many more studies of this nature will follow.

\section{Contributions: A reorientation of textbooks to promote open conversations}

It has been argued that students leave tertiary education with a strong grasp of common management perspectives, but without a strong notion that these perspectives can be approached critically. While it is not necessarily deliberate, teaching a management 'canon' inevitably excludes other approaches. As an alternative, textbooks could be framed as the start of an open conversation (Carroll et al., 2018; Fougère \& Moulettes, 2011). A decent model for textbooks presenting contrasting versions of stories is the aforementioned integration of Wrege and Perroni's critical Frederick Taylor analysis into more recent textbooks. More recently Knights and Willmott (2017) is an example of presenting the sense of an open conversation. There are many examples in their textbook to illustrate this: one of these is a discussion of Tuckman's (1965) well-known forming-storming-normingperforming model, offering four stages that are said to describe the evolution and development of a group over time. After presenting the usual theory, they mention Tuckman's own criticism of the applicability of the model and quote a later study by Gersick (1988) observing group work as a much less continuous process than Tuckman's model indicates, instead being one of continuous instability and disruption. A similar approach can be taken with groupthink, with both versions being discussed with clarity. This can give students more of a sense that they are participating in a contested terrain - an ongoing debate in which multiple perspectives and narratives can be valid. 


\section{Contributions: Embracing history meaningfully}

A valuable aspect of reading Whyte's original work is that he calls several times for a return to the humanities, as a response to management becoming too slanted towards a purely scientific focus. This echoes more recent arguments regarding management history, including Burrell's $(1997,185)$ claim that business' separation from endeavours such as philosophy, literature and history "has created a lesion which has virtually lobotomized whole areas of intellectual endeavour" and "allowed business teachers to escape without any real sensitivity to the issues raised by the humanities" (185). In terms of recommendations for teaching, the embrace of humanities fields, including history, is also relevant. Cummings et al. (2016) argued for researchers and teachers to look back and read commonly referenced texts from the past rather than just citing them. Rediscovering rarely cited academic texts would also be valuable. Looking to the past allows a "liberation from the present: one that inspires use to be more 'retro-active' so as to recreate what we see as historically important" (Cummings et al., 2016, 53). And engaging directly with historical sources is a clear way of reaching such decisions but is too rarely attempted. Academics do not need to act as the sole gatekeepers of what is perceived as valuable either. Educators setting complete historical readings as texts would benefit from seeking feedback from their students to determine which ideas inspire the greatest sense of interest and relevance, and why. Whyte's 1952 article (and Janis' 1971 article) could be set as course readings, sending students directly to the original source of these ideas, unencumbered by more recent representations.

\section{Conclusion: The value of teaching Whyte's ideas}

The implicit argument that textbooks make by continuing to discuss groupthink is that the term is a valuable one to teach students. I agree. But I propose that management studies could continue to use the term but discussing Whyte's interpretation alongside Janis'. This would still maintain the evidently memorable word to describe organisational decision-making, but with a valuable addition in the form of recognising Whyte's more critical insights into group decision-making as a wider systemic issue. Ultimately, Whyte's marginalisation exemplifies the management field's tendency towards obscuring less palatable ideas. While there are many histories, none of which can fully represent the past accurately, it is notable that management scholars and textbooks tend to stick rigidly to one form of events, with little variation. These are often clear and simple in order to be teachable, but we must consider 
what is lost during this process. While Whyte's ideological sympathies can be hard to pin down, it can certainly be said that he utilised management theory to try to contribute to human welfare (Starbuck, 2003) and to fight for the individual. There is a sense of Whyte's work deliberately disrupting the status quo, not accepting the power and prestige of the social scientists as he perceived that they used their significant influence for manipulation rather than instruction. A return to Whyte's work, and to the original conception of groupthink, can contribute towards management educators embracing the value of a more critical evaluation of the field, and to "pay much more attention to the historical evolution of practice and policy and much more attention to the deconstruction and cultural analysis of ruling concepts and theories" (Zald, 2002, 382). 


\section{CHAPTER 7 - Conclusion}

This thesis was sparked by curiosity about the consistent citation of Janis in management textbooks despite clear evidence that the groupthink term was not originally his. There was no expectation of one definitive answer. The multi-factorial counter-history presented here is a narrative constructed based on close attentiveness to historical data sources, and while it has largely satisfied my own curiosity, other narratives are possible. Recognising this as a strength rather than a limitation has been an important part of embracing critical historical study. This study adds to the relatively underexplored study of management learning via archival research, in the hope that many more will follow. But this method is not perfect. An inherent limitation is the data-collection process, and the centrality of the use of keywords and citations to determine references to authors and groupthink. Some textbooks searched through, physically and digitally, may have contained coverage of groupthink that was not cited, or attributed to the wrong author or text. A few examples of this have been caught and have fortunately found their way into the data, but their existence makes it likely that others have slipped through the net.

Whyte left the idea of groupthink behind, moving on to city planning. But my research has found that the fundamental core of his ideas never really changed throughout his lifetime. The same is evidently not true of management studies and is best illustrated by the depictions of new editions of the same textbooks, showing a definite process of Whyte's groupthink being discarded. The data also points to a consistently managerial textbook interpretation of Janis' groupthink, and a rarely changing representation of his eight symptoms framework. The thesis consistently discusses the inherent subjectivity of creating any sort of historical narrative, and the same is true of this work. Based on my research, I have created a history that highlights the value of the work of both Whyte and Janis but concludes that Whyte's may be more relevant from a perspective of embracing the possibility of criticism of management and human relations. This is not objectively true, since nothing is, but it is a conclusion that I am satisfied with based on my research. I would be eager to see other conclusions.

Future research is important here. In the section about why Janis prevailed, I focused on the continued references to his case studies based on historic fiascos, and the lack of further empirical evidence or cohesive application of his ideas to a broader organisational level. I make a claim for Whyte as a potentially more complex and relevant inclusion in management 
textbooks. In practice, this may be more difficult. Whyte's groupthink has been lost in the wilderness for decades - a rushed reintroduction would be problematic. It needs to be assessed and discussed - how does it fit into 2020? I have attempted here to provide a solid start to this discussion, offering Whyte as another case study illustrating the management ideas that are needlessly forgotten. But I accept that further study may need to be done. This could (but does not need to) include empirical research of the sort attempted with Janis. This thesis is about allowing William $\mathrm{H}$. Whyte to be heard again. Whether people want to listen to him remains to be seen. 


\section{$\underline{\text { References }}$}

't Hart, P., Stern, E.K., \& Sundelius, B. (Eds.) (1997). Beyond groupthink: political group dynamics and foreign policy-making. University of Michigan Press.

Aldag, R.J., \& Fuller, S.R. (1993). Beyond fiasco: A reappraisal of the groupthink phenomenon and a new model of group decision processes. Psychological Bulletin, 113 (3), 533-552

Aldrich, H.E., \& Ruef, M. (2006). Organizations evolving (2 ${ }^{\text {nd }}$ ed.). Sage.

Alvesson, M., \& Sköldberg, K. (2009). Reflexive methodology: New vistas for qualitative research ( $2^{\text {nd }}$ ed.). Sage.

Alvesson, M., \& Willmott, H. (Eds.). (1992). Critical management studies. Sage.

Alvesson, M., \& Willmott, H. (1996). Making sense of management: A critical introduction. Sage.

Alvesson, M., Bridgman, T., \& Willmott, H. (2009). The Oxford handbook of critical management studies. Oxford University Press.

Argyris, C. (1957). Personality and organization. Harper \& Row.

Athos, A.G., \& Coffey, R.E. (1968). Behavior in organizations: A multidimensional view. Prentice Hall.

Atlanta Jewish Times (2019, Oct 8). Obituary: Selma Sanker Wolff. Atlanta Jewish Times. https://atlantajewishtimes.timesofisrael.com/obituary-selma-sanker-wolff/

Badie, D. (2010). Groupthink, Iraq, and the war on terror: Explaining US policy shift toward Iraq. Foreign Policy Analysis, 6(4), 277-296.

Bahmer, R.H. (1963). The management of archival institutions. The American Archivist, 26(1), 3-10. 
Balsley, T. (2006). Sowing the seeds. In R.H. Platt (Ed.), The humane metropolis (p. 37). University of Massachusetts Press.

Baritz, L. (1960). The servants of power: A history of the use of social science in American industry. Wesleyan University Press.

Bartol, K.M., \& Martin, D.C. (1991). Management (Int. ed.). McGraw-Hill.

Bass, B.M. (1960). Leadership, psychology, and organizational behavior. Harper \& Row.

Bass, B.M., \& Barrett, G.V. (1972). Man, work and organizations. Allyn and Bacon.

Bedeian, A.G. (1986). Management. CBS College Publishing.

Beder, S. (2006). Free market missionaries: The corporate manipulation of community values. Earthscan.

Bell, E., \& Taylor, S. (2013). Writing history into management research. Management \& Organizational History, 8(2), 127-136.

Bennis, W.G., Schein, E.H., \& McGregor, C. (Eds.) (1966). Leadership and motivation: Essays of Douglas McGregor. The M.I.T. Press.

Bensman, J., \& Vidich, A.J. (1971). The new American society. Quadrangle Books.

Bernstein, M. (1952). Is anybody listening? Review. The Public Opinion Quarterly, 16 (2), 296-300.

Birch, E.L. (1986). The observation man, a study of William H. Whyte. Departmental Papers (City and Regional Planning), 21.

Blaisdell, D.C. (1957). American democracy under pressure. Ronald Press.

Blau, P.M. (1956). Bureaucracy in modern society. Random House. 
Bowditch, J.L., Buono, A.F., \& Stewart, M.M. (2008). A primer on organizational behavior (7 ${ }^{\text {th }}$ ed.). John Wiley \& Sons.

Bridgman, T., Cummings, S., \& Ballard, J. (2019). Who built Maslow's pyramid? A history of the creation of management studies' most famous symbol and its implications for management education. Academy of Management Learning and Education, 18(1), 81-98.

Bridgman, T., Cummings, S., McLaughlin, C. (2016). Restating the case: How revisiting the development of the case method can help us think differently about the future of the business school. Academy of Management Learning and Education, 15(4), 724-741.

Brooke, M.Z. (1984). Centralization and autonomy. Holt, Rinehart and Winston.

Brooks, I. (1999). Organisational behaviour. Pearson Education.

Bryman, A., \& Bell, E. (2011). Business research methods ( $3^{\text {rd }}$ ed.). Oxford University Press.

Bucheli, M., \& Wadhwani, R. D. (2014). Organizations in time: History, theory, methods. Oxford University Press.

Burrell, G. (1997). Pandemonium: Towards a retro-organization theory. Sage.

Byrt, W.J. (1980). The human variable. McGraw-Hill.

Callaway, M.R., \& Esser, J.K. (1984). Groupthink: Effects of cohesiveness and problem-solving procedures on group decision making. Social Behavior and Personality, 12(2), 157-164.

Cameron, K.S., Ireland, R.D., Lussier, R.N., New, J.R., Robbins, S.P. (2003). Management textbooks as propaganda. Journal of Management Education, 27(6), 711-729.

Carroll, B., Firth, J., Ford, J., Taylor, S. (2018). The social construction of leadership studies: Representations of rigour and relevance in textbooks. Leadership, 14 (2), 159-178. 
Cartwright, D., \& Lippitt, R. (1964). Group dynamics and the individual. In H.J. Leavitt \& L.R. Pondy (Eds.), Readings in managerial psychology (pp. 286-303). University of Chicago Press.

Cascio, W.F. (1978). Applied psychology in personnel management. Reston.

Certo, S.C. (1994). Modern management: Diversity, quality, ethics, and the global environment $\left(6^{\text {th }}\right.$ ed.). Allyn and Bacon.

Cheit, E.F. (1964). Why managers cultivate social responsibility. California Management Review, 7(1), 3-22.

Chell, E. (1993). The psychology of behaviour in organizations ( $2^{\text {nd }}$ ed.). Macmillan Press.

Childs, M.W., \& Cater, D. (1954). Ethics in a business society. Harper \& Brothers.

Clark, P., \& Rowlinson, M. (2004). The treatment of history in organisation studies: Towards an ‘historic turn'? Business History, 46(3), 331-352.

Clegg, S., \& Lounsbury, M. (2009), "Sintering the iron cage: translation, domination, and rationality”. In P.S Adler (Ed.), The Oxford handbook of sociology and organization studies. Classical foundations (pp. 118-145). Oxford University Press.

Clegg, S.R., Kornberger, M., Pitsis, T.S., \& Mount, M. (2019). Managing \& organizations: An introduction to theory and practice ( $5^{\text {th }}$ ed.). Sage.

Coates, C.H., \& Pellegrin, R.J. (1957). Executives and supervisors: Informal factors in differential bureaucratic promotion. Administrative Science Quarterly, 2(2), 200-215.

Cooke, B. (1999). Writing the left out of management theory: The historiography of the management of change. Organization, 6(1), 81-105. 
Cooke, B. (2003). The denial of slavery in management studies. Journal of Management Studies, 40(8), 1895-1918.

Cooke, B., Mills, A.J., \& Kelley, E.S. (2005). Situating Maslow in Cold War America. Group and Organization Management, 30(2), 129-152.

Courtright, J. A. (1978). A laboratory investigation of groupthink. Communication Monographs, 45(3), 229-246.

Cummings, S., \& Bridgman, T. (2011). The relevant past: Why the history of management should be critical for our future. Academy of Management Learning and Education, 10(1), 77-93.

Cummings, S., \& Bridgman, T. (2016). The limits and possibilities of history: How a wider, deeper, and more engaged understanding of business history can foster innovative thinking. Academy of Management Learning and Education, 15(2), 250-267.

Cummings, S., Bridgman, T., \& Brown, K.G. (2016). Unfreezing change as three steps: Rethinking Kurt Lewin's legacy for change management. Human Relations, 69(1), 33-60.

Cummings, S., Bridgman, T., Hassard, J., \& Rowlinson, M. (2017). A new history of management. Cambridge University Press.

Dalton, M. (1959). Men who manage: Fusions of feeling and theory in administration. John Wiley \& Sons.

Davis, K. (1957). Human relations in business ( $1^{\text {st }}$ ed.). McGraw-Hill.

Davis, K. (1962). Human relations at work (2 ${ }^{\text {nd }}$ ed.). McGraw-Hill.

Davis, K. (1963). Togetherness: The informal variety. In D.M. Bowman, \& F.M. Fillerup (Eds.), Management: Organization and planning (pp. 41-52). McGraw-Hill. 
Davis, K. (1967). Human relations at work: The dynamics of organizational behavior ( $3^{\text {rd }}$ ed.). McGraw-Hill.

Davis, K. (1972). Human behavior at work: Human relations and organizational behavior (4 ${ }^{\text {th }}$ ed.). McGraw-Hill.

Davis, K. (1977). Human behavior at work: Organizational behavior (5 ${ }^{\text {th }}$ ed.). McGraw-Hill.

Davis, K. (1981). Human behavior at work: Organizational behavior (6 ${ }^{\text {th }}$ ed.). McGraw-Hill.

Davis, K., \& Newstrom, J.W. (1985). Human behavior at work: Organizational behavior (7 ${ }^{\text {th }}$ ed.). McGraw-Hill.

Dean, V.M. (1952). The United States and India. Far Eastern Survey, 21(5), 41-46.

Decker, S. (2013). The silence of the archives: Business history, post-colonialism and archival ethnography. Management and Organizational History, 8(2), 155-173.

Deetz, S. (1992). Democracy in an age of corporate colonization: Developments in communication and the politics of everyday life. State University of New York Press.

Dowling, J., \& Pfeffer, J. (1975). Organizational legitimacy: Social values and organizational behavior. The Pacific Sociological Review, 18(1), 122-136.

Dreyfus, H.L., \& Rabinow, P. (1982). Michel Foucault: Beyond structuralism and hermeneutics. University of Chicago Press.

Drucker, P. (1954). The practice of management. Harper \& Row.

Drummond, H. (2000). Introduction to organizational behaviour. Oxford University Press.

Dunford, R.W. (1992). Organisational behaviour: An organisational analysis perspective. AddisonWesley. 
Dye, K., Mills, A.J., \& Weatherbee, T. (2005). Maslow: man interrupted: reading management theory in context. Management Decision, 43(10), 1375-1395.

Eenigenburg, E.M. (1961). Togetherness, biblical and otherwise. Reformed Review, 14(4), 1-14.

Elkin, G., \& Inkson, K. (2000). Organisational behaviour in New Zealand. Pearson Education.

Feldman, D.C., \& Arnold, H.J. (1983). Managing individual and group behavior in organizations. McGraw-Hill.

Fineman, S., \& Gabriel, Y. (1994). Paradigms of organizations: An exploration in textbook rhetorics. Organization, 1(2), 375-399.

Fletcher, J.K., Bailyn, L., \& Beard, S.B. (2009). Practical pushing: creating discursive space in organizational narratives. In J. Wolfram Cox, T.G. LeTrent-Jones, M. Voronov, \& D. Weir (Eds.) Critical management studies at work: Negotiating tensions between theory and practice. (pp. 82-93). Edward Elgar.

Flowers, M.L. (1977). A laboratory test of some implications of Janis' groupthink hypothesis. Journal of Personality and Social Psychology, 35(12), 888-896.

Foell, E.W. (1965, Feb 12). More cultural gold along with the dross. The Christian Science Monitor, 9.

Foltman, F.F. (1964). Review: Executive skills: Their dynamics and development. ILR Review, 17(4), 654-655.

Foster, J., Mills, A.J., \& Weatherbee, T.G. (2014). History, field definition and management studies: The case of the New Deal. Journal of Management History, 20(2), 179-189.

Foucault, M. (1978). The history of sexuality: An introduction. Random House. 
Foucault, M. (1980). Power/knowledge. Selected interviews and other writings 1972-77. Harvester Press.

Foucault, M. (1985). The history of sexuality: Volume two - the use of pleasure. Pantheon.

Fougère, M., \& Moulettes, A. (2011). Disclaimers, dichotomies and disappearances in international business textbooks: A postcolonial deconstruction. Management Learning, 43(1), 5-24.

Fox, J. (2013, June 5). The bedraggled return of the organization man. Harvard Business Review, https://hbr.org/2013/06/the-bedraggled-return-of-the-orga.html.

Gable, R.W. (1953). NAM: Influential lobby or kiss of death? The Journal of Politics, 15(2), 254273.

Galbraith, J.K. (1958). The affluent society. Houghton Mifflin.

Gersick, C.J.G. (1988). Time and transition in work teams: Toward a new model of group development. Academy of Management Journal, 31(1), 9-41.

Godfrey, P.C., Hassard, J., O’Connor, E.S., Rowlinson, M., \& Ruef, M. (2016). What is organizational history? Toward a creative synthesis of history and organization studies. Academy of Management Review, 41(4), 590-608.

Golembiewski, R.T. (1965). Men, management, and morality: Toward a new organizational ethic. McGraw-Hill.

Gordon, J.R. (1993). A diagnostic approach to organizational behavior (4 ${ }^{\text {th }}$ ed.). Allyn and Bacon.

Gordon, R.A., \& Howell, J.E. (1959). Higher education for business. Columbia University Press.

Gouldner, A.W. (1954). Patterns of industrial democracy. The Free Press. 
Grant, J. D., \& Mills, A. J. (2006). The quiet Americans: Formative context, the Academy of Management leadership, and the management textbook, 1936-1960. Management and Organizational History, 1(2), 201-224.

Green, A., \& Troup, K. (2016). The houses of history: A critical reader in history and theory $\left(2^{\text {nd }}\right.$ ed.). Manchester University Press.

Greenberg, J., \& Baron, R.A. (1993). Behavior in organizations: Understanding \& managing the human side of work ( $4^{\text {th }}$ ed.). Allyn and Bacon.

Greenberg, J., \& Baron, R.A. (1995). Behavior in organizations: Understanding \& managing the human side of work (5 $5^{\text {th }}$ ed.). Prentice-Hall.

Gross, B.M. (1964a). The managing of organizations: The administrative struggle. Volume I. Glencoe.

Gross, B.M. (1964b). The managing of organizations: The administrative struggle. Volume II. Glencoe.

Groves, M. (1999, Jan 24). Lessons from ‘The Organization Man' still have some relevance for today. Los Angeles Times. https://www.latimes.com/archives/la-xpm-1999-jan-24-fi-1115story.html.

Hanson, D., \& O’Donohue, W. (2010). William Whyte’s ‘The Organization Man': A flawed central concept but a prescient narrative. Management Revue, 21(1), 95-104.

Harding, N. (2003). The social construction of management: texts and identities. Routledge.

Hassard, J.S. (2012). Rethinking the Hawthorne Studies: The Western Electric research in its social, political and historical context. Human Relations, 65(11), 1431-1461. 
Hoban, C.F. (1953). Determinants of audience reaction: Status. Audiovisual Communication Review, $1(4), 242-251$.

Hodgetts, R.M., \& Altman, S. (1979). Organizational behavior. W.B. Saunders.

Hodgson, G. (1999, 15 Jan). Obituary: William H Whyte: Secret life of US corporations. The Guardian, 20.

Hovland, C.I., Janis, I.L., \& Kelley, H.H. (1953). Communication and persuasion; psychological studies of opinion change. Yale University Press.

Huczynski, A., \& Buchanan, D. (2001). Organizational behaviour: An introductory text. Pearson Education.

Irving Janis dies at 72; coined 'group think'. (1990, Nov 18). New York Times, 44.

Jacobs, J. (1961). The death and life of great American cities. Random House.

Jacques, R. (1996). Manufacturing the employee. Sage.

Jäger, S., \& Maier, F. (2016) Analysing discourses and dispositives: A Foucauldian approach to theory and methodology. In R. Wodak, \& M. Meyer (Eds.), Methods of critical discourse studies (pp. 110-135). Sage.

Janis, I.L. (1971). Groupthink. Psychology Today, 26, 43-76.

Janis, I.L. (1972). Victims of groupthink. Houghton Mifflin.

Janis, I.L. (1982). Groupthink: Psychological studies of policy decisions and fiascoes. Houghton Mifflin.

Janis, I.L., \& Feshbach, S. (1953). Effects of fear arousing communications. The Journal of Abnormal and Social Psychology, 48(1), 78-92. 
Janis, I.L., \& King, B.T. (1954). The influence of role playing on opinion change. Journal of Abnormal and Social Psychology, 49(2), 211-218.

Janis, I.L., \& Mann, L. (1977). Decision making: A psychological analysis of conflict, choice, and commitment.

Jenkins, K. (1991). Re-thinking history. Routledge.

Jenkins, K. (2003). Refiguring history: New thoughts on an old discipline. Routledge.

Johns, G. (1996). Organizational behavior: Understanding and managing life at work (4 ${ }^{\text {th }}$ ed.). HarperCollins.

Jordanova, L. (2006). History in practice (2 $2^{\text {nd }}$ ed.). Bloomsbury.

Kalliath, T., Brough, P., O’Driscoll, M., Manimala, M.J., \& Siu, O. (2010). Organisational behaviour: A psychological perspective for the Asia-Pacific. McGraw-Hill.

Karlins, M., \& Abelson, H.I. (1970). Persuasion: How opinions and attitudes are changed (2 ${ }^{\text {nd }}$ ed.). Crosby Lockwood \& Son.

Kaufman, M.T. (1999, Jan 13). William H. Whyte, 'Organization Man’ author and urbanologist, is dead at 81. The New York Times.

Keltner, J.W. (1957). "Groupthink” and individual thinking. Today's Speech, 5(2), 5-6.

Keyton, J. (2005). Communication and organizational culture: A key to understanding work experiences. Sage.

Khurana, R. (2007). From higher aims to hired hands: The social transformation of American business schools and the unfulfilled promise of management as a profession. Princeton University Press. 
Kieser, A. (1994). Why organization theory needs historical analysis - and how this should be performed. Organization Science, 5(4), 608-620.

King, D., \& Lawley, S. (2019). Organizational behaviour (3 ${ }^{\text {rd }}$ ed.). Oxford University Press.

Knights, D., \& Willmott, H. (2017). Introducing organizational behaviour and management (3 ${ }^{\text {rd }}$ ed.). Cengage Learning.

Koontz, H., \& O’Donnell, C. (1968). Principles of management: An analysis of managerial functions ( $4^{\text {th }}$ ed.). McGraw-Hill.

Kreitner, R., \& Kinicki, A. (2008). Organizational behavior ( $8^{\text {th }}$ ed.). McGraw-Hill.

Lawless, D.J. (1972). Effective management: Social psychological approach. Prentice-Hall.

Lawless, D.J. (1979). Organizational behavior (2 ${ }^{\text {nd }}$ ed.). Prentice-Hall.

Leana, C.R. (1985). A partial test of Janis' groupthink model: Effects of group cohesiveness and leader behavior on defective decision making. Journal of Management, 11(1), 5-17.

Leavitt, H.J. (1958). Managerial psychology. University of Chicago Press.

Leavitt, H.J. (1972). Managerial psychology ( $3^{\text {rd }}$ ed). University of Chicago Press.

Leavitt, H.J. (1978). Managerial psychology (4 ${ }^{\text {th }}$ ed). University of Chicago Press.

Leavitt, H.J., \& Bahrami, H. (1988). Managerial psychology: Managing behavior in organizations ( $5^{\text {th }}$ ed.). University of Chicago Press.

Leavitt, H.J., Pondy, L.R., \& Boje, D.M. (Eds.) (1980). Readings in managerial psychology (3 ${ }^{\text {rd }}$ ed.). University of Chicago Press.

Leblebici, H., Shah, M. (2004). The birth, transformation and regeneration of business incubators as new organisational forms: Understanding the interplay between organisational history and organisational theory. Business History, 46(3), 353-380. 
Lewis, M. (1997, Oct 30). The new organization man. Slate. https://slate.com/culture/1997/10/thenew-organization-man.html

Litwak, E. (1960). Occupational mobility and extended family cohesion. American Sociological Review, 25(1), 9-21.

Longenecker, J.G. (1969). Principles of management and organizational behavior (2 ${ }^{\text {nd }}$ ed.). Charles E. Merrill.

Luthans, F. (1989). Organizational behavior ( $5^{\text {th }}$ ed.). McGraw-Hill.

Maclean, M., Harvey, C., \& Clegg, S.R. (2016). Conceptualising historical organization studies. Academy of Management Review, 41(4), 609-632.

Mayer, R.C., Davis, J.H., \& Schoorman, F.D. (2006). An integrative model of organizational trust. In R.M. Kramer (Ed.), Organizational trust: A reader (pp. 82-110). Oxford University Press.

McClung Lee, A. (1953). Review: Is anybody listening? American Journal of Sociology, 58(4), 437 438.

McGregor, D. (1958). The Scanlon Plan through a psychologist's eyes. In F.G. Lesieur (Ed.), The Scanlon Plan: A frontier in labor-management cooperation (pp. 89-99). John Wiley \& Sons.

McGuire, J.W. (1964). Theories of business behavior. Prentice-Hall.

McLaren, P. G. (2019). Stop blaming Gordon and Howell: Unpacking the complex history behind the research-based model of education. Academy of Management Learning and Education, 18(1), 43-58.

McMurray, R.N. (1958). The case for benevolent autocracy. Harvard Business Review, 36(1), 82-90.

McNair, M.P. (1957). Thinking ahead: What price human relations? Harvard Business Review, $35(2), 15-23$. 
Merton, R.K. (1957). Social theory and social structure. Free Press.

Mills, A.J., Weatherbee, T.G., \& Durepos, G. (2014). Reassembling Weber to reveal the-past-ashistory in management and organization studies. Organization, 21(2), 225-243.

Mills, C.W. (1951). White collar: The American middle classes. Oxford University Press.

Mills, C.W. (1956a). The power elite. Oxford University Press.

Mills, C.W. (1956b, Dec. 9) Crawling to the top. The New York Times, p. 6 \& p. 26.

Miner, J.B. (1963). The management of ineffective performance. McGraw-Hill.

Miner, J.B. (2006). Organizational behavior 3: Historical origins, theoretical foundations, and the future. Sharpe.

Mir, A. (2003). The hegemonic discourse of management texts. Journal of Management Education, 27(6), 734-738.

Mohamed, A.A., \& Wiebe, F.A. (1996). Toward a process theory of groupthink. Small Group Research, 27(3), 416-430.

Moorhead, G. (1982). Groupthink: Hypothesis in need of testing. Group \& Organization Studies, 7(4), 429-444.

Moorhead, G., \& Griffin, R.W. (1992). Organizational behavior: Managing people and organizations ( ${ }^{\text {rd }}$ ed.). Houghton Mifflin.

Moorhead, G., \& Montanari, J.R. (1986). An empirical investigation of the groupthink phenomenon. Human Relations, 39(5), 399-410.

Morley, I.E., \& Hoskin, D.M. (1984). Decision-making and negotiation. In M. Gruneberg \& T. Wall (Eds.), Social psychology and organizational behaviour (pp. 71-92). John Wiley \& Sons.

Munslow, A. (2003). The new history. Pearson Longman. 
Newstrom, J.W. (2007). Organizational behavior: Human behavior at work (12 ${ }^{\text {th }}$ ed.). McGraw-Hill.

Nocera, J. (2002). Foreword. In W.H. Whyte, The organization man. University of Pennsylvania Press.

Novick, P. (1988). That noble dream: The "objectivity question" and the American historical profession. Cambridge University Press.

O’Connor, E.S. (1999). The politics of management thought: A case study of the Harvard Business School and the human relations school. Academy of Management Review, 24(1), 117-131.

Orwell, G. (1949). 1984. Secker \& Warburg.

Ott, J.S. (1989). The organizational culture perspective. Dorsey Press.

Park, W.-W. (1990). A review of research on groupthink. Journal of Behavioral Decision Making, $3(4), 229-245$.

Perlmutter, D. D. (1997). Manufacturing visions of society and history in textbooks. Journal of Communication, 47(3), 68-81.

Peters, T.J., \& Waterman, R.H. (1982). In search of excellence. Harper \& Row.

Pheysey, D.C. (1993). Organizational cultures. Routledge.

Polman, D. (1987, 15 Feb). Organization man: Still valid after 3 decades. Philadelphia Inquirer, K.1.

Popper, D.E., \& Popper, F.J. (2006). "The organization man” in the twenty-first century: An urbanist view. In R.H. Platt (Ed.), The humane metropolis (pp. 206-219). University of Massachusetts Press.

Prieto, L.C., \& Phipps, S.T.A. (2016). Re-discovering Charles Clinton Spaulding's “The administration of big business". Journal of Management History, 22(1), 73-90. 
Prieto, L.C., \& Phipps, S.T.A. (2019). African American management history: Insights on gaining a cooperative advantage. Emerald.

Radford, G.P., \& Radford, M.L. (2005). Structuralism, post-structuralism, and the library: de Saussure and Foucault. Journal of Documentation, 61(1), 60-78.

Redding, W.C., \& Tompkins, P.K. (1988). Organizational communication: Past and present tenses. In G. Goldhaber \& G. Barnett (Eds.), Handbook of organizational communication (pp. 5-34). Ablex.

Riesman, D., Denny, R., \& Glazer, N. (1950). The lonely crowd; a study of the changing American character. Yale University Press.

Robbins, S. P. (1997). Managing today. Prentice Hall.

Robbins, S., \& Mukerji, D. (1990). Managing organisations: New challenges and perspectives. Prentice Hall.

Robbins, S.P., \& Judge, T.A. (2009). Organizational behavior $\left(13^{\text {th }}\right.$ ed.). Prentice Hall.

Robbins, S.P., DeCenzo, D.A., Coulter, M., \& Woods, M. (2016). Management: The essentials (3 ${ }^{\text {rd }}$ ed.). Pearson Australia.

Roberts, K.H., \& Hunt, D.M. (1991). Organizational behavior. PWS-Kent.

Roethlisberger, F. and Dickson, W. (1939) Management and the worker. Harvard University Press.

Rowlinson, M., Hassard, J., \& Decker, S. (2014). Research strategies for organizational history: A dialogue between historical theory and organization theory. Academy of Management Review, $39(3), 250-274$. 
Rowlinson, M., Stager Jacques, R., \& Booth, C. (2009). Critical management and organization history. In M. Alvesson, H. Willmott, \& T. Bridgman (Eds.), The Oxford handbook of critical management studies (pp.286-305). Oxford University Press.

Russett, B. (1991). In memoriam: Irving L. Janis. Journal of Conflict Resolution, 35(2), 179-180.

Sandberg, J., \& Targama, A. (2007). Managing understanding in organizations. Sage.

Schermerhorn, J. R. (1989). Management for productivity ( $3^{\text {rd }}$ ed.). John Wiley \& Sons.

Schermerhorn, J. R. (1996). Management and organizational behavior essentials. John Wiley \& Sons.

Schermerhorn, J.R., Hunt, J.G., \& Osborn, R.N. (1995). Basic organizational behavior. John Wiley \& Sons.

Schwartzman, H.B. (1989). The meeting: Gathering in organizations and communities. Plenum Press.

Silk, L., \& Vogel, D. (1976). Ethics and profits. Simon and Schuster.

Simon and Schuster. (1952, Apr 7). Is anybody listening [Advertisement]. Wall Street Journal, 8.

Stambaugh, J. E., \& Trank, C. Q. (2010). Not so simple: Integrating new research into textbooks. Academy of Management Learning and Education, 9(4), 663-681.

Starbuck, W.H. (1965). Organizational growth and development. In J.G. March (Ed.), Handbook of Organizations (pp. 451-583). Rand McNally.

Starbuck, W.H. (2003). Shouldn’t organization theory emerge from adolescence? Organization, $10(3), 439-452$.

Stewart, R. (1967). The reality of management ( $2^{\text {nd }}$ ed.). Pan Books.

Stoner, J.A.F. (1982). Management ( $2^{\text {nd }}$ ed.). Prentice Hall. 
Stoner, J.A.F., \& Wankel, C. (1986). Management (3 ${ }^{\text {rd }}$ ed.). Prentice Hall.

Strati, A. (2000). Theory and method in organization studies. Sage.

Suddaby, R., Foster, W. M., \& Mills, A. J. (2014). Historical institutionalism. In M. Bucheli \& R. D. Wadhwani (Eds.), Organizations in time: History, theory, methods (pp. 100-123.) Oxford University Press.

Tannenbaum, R. (1959). Some current issues in human relations. California Management Review, 2(1), 49-58.

Tannenbaum, R., Weschler, I.R., \& Massarik, F. (1961). Leadership and organization. McGrawHill.

Tetlock, C.N.P. (1991). Irving L. Janis, psychology: Berkeley. In University of California (Ed.), University of California: In Memoriam, 1991 (pp. 91-93).

Thomas, J.L. (1957). The significance of cultural pluralism. Religious Education, 52(6), 420-424.

Thompson, V. A. (1961). Modern organization. Alfred A. Knopf.

Tough, A. (1979). The adult's learning projects ( $2^{\text {nd }}$ ed.). Learning Concepts.

Trice, H.M., \& Beyer, J.M. (1993). The cultures of work organizations. Prentice Hall.

Tuckman, B.W. (1965). Developmental sequence in small groups. Psychological Bulletin, 63(6), 384-399.

Turner, J.H., Filley, A.C., \& House, R.J. (1972). Studies in managerial process and organizational behavior. Scott, Foresman and Company.

Turner, M.E., Pratkanis, A.R., Probasco, P., \& Leve, C. (1992). Threat, cohesion, and group effectiveness: Testing a social identity maintenance perspective on groupthink. Journal of Personality and Social Psychology, 63(5), 781-796. 
Vance, S. (1959). Industrial administration. McGraw-Hill.

Vasu, M.L., Stewart, D.W., \& Garson, G.D. (1998). Organizational behavior and public management ( $3^{\text {rd }}$ ed.). Marcel Dekker.

Watson, R. (1997). Ethnomethodology and textual analysis. In D. Silverman (Ed.), Qualitative research: Theory, method and practice (pp. 80-98). Sage.

Wekselberg, V. (1996). Groupthink: A triple fiasco in social psychology. In C.W. Tolman, F.

Cherry, R. Van Hezewijk, \& I. Lubek (Eds.), Problems of theoretical psychology (pp. 217227). Captus Press.

Wexley, K.N., \& Yukl, G.A. (1984). Organizational behavior and personnel psychology. Irwin.

Whyte, G. (1989). Groupthink reconsidered. Academy of Management Review, 14(1), 40-56.

Whyte, W.H. (1986, Dec 7). 'Organization man' revisited; the organization man: A rejoinder. The New York Times, S6, p. 98

Whyte, W.H. (1952a). Groupthink. Fortune. https://fortune.com/2012/07/22/groupthink-fortune-1952/: 115

Whyte, W.H. (1952b). Is anybody listening? Simon and Schuster.

Whyte, W.H. (1956). The organization man. Simon and Schuster.

Whyte, W.H. (1972, Dec. 3). Please, just a nice place to sit. The New York Times.

Wiley-Schwartz, A.G. (2006). The smile index. In R.H. Platt (Ed.), The humane metropolis (pp. 236239). University of Massachusetts Press.

Williams, K.S., \& Mills, A.J. (2017). Frances Perkins: gender, context and history in the neglect of a management theorist. Journal of Management History, 23(1), 32-50. 
Willmott, H. (1993). Strength is ignorance; slavery is freedom: Managing culture in modern organizations. Journal of Management Studies, 30(4), 515-552.

Wood, J., Zeffane, R., Fromholtz, M., \& Fitzgerald, A. (2006). Organizational behaviour: Core concepts and applications ( $1^{\text {st }}$ Australasian ed.). John Wiley \& Sons.

Wrege, C. D., \& Perroni, A. G. (1974). Taylor's pig tale: A historical analysis of Frederick W. Taylor's pig-iron experiments. Academy of Management Journal, 17(1), 6-27.

Wren, D. (1972). The evolution of management thought. The Ronald Press Company.

Wren, D. (1979). The evolution of management thought ( $2^{\text {nd }}$ ed.). John Wiley \& Sons.

Wren, D. (1987). The evolution of management thought ( $3^{\text {rd }}$ ed.). John Wiley \& Sons.

Wren, D.A., \& Bedeian, A.G. (2009). The evolution of management thought (6 $6^{\text {th }}$ ed.). John Wiley \& Sons.

Zald, M.N. (2002). Spinning disciplines: Critical management studies in the context of the transformation of management education. Organization, 9(3), 365-385. 